Sanford M. Jacoby*

\title{
Executive Pay and Labor's Shares: Unions and Corporate Governance from Enron to Dodd-Frank
}

\author{
https://doi.org/10.1515/ael-2019-0073
}

\begin{abstract}
This article is an historical analysis of the U.S. labor movement's shareholder activism during the 2000s, which was based on their pensionplan assets. During the previous decade, corporate governance had tilted to give shareholders greater voice in corporate decisions. The protagonists were public pension plans such as CalPERS. Come the 2000s, they were replaced by unions and union-influenced pension plans. Their agendas overlapped but union investors were distinctive in their use of shareholder activism to make companies more public-minded, raise labor's organizing power, and challenge executive power by reliance not only on shareholder activism but also political activities. Labor's signature issue was executive pay, which was a topic that that shareholder activists during the 1990s had avoided other than to push for stock-based pay. But three waves of corporate scandals during the following decade caused other shareholders to become skeptical of executive pay-setting methods. Union investors zeroed in on expensing and backdating of stock options, and fought for say on pay, the issue where they had the greatest impact. An interaction between private orderings and regulation now developed, whereby shareholder pay reforms found their way into law. With inequality a major social concern, unions repeatedly contrasted lofty executive pay to stagnant wages. Yet little was said about lofty payouts to shareholders, which may have been a more important driver of inequality than executive pay. The article ties corporate governance to larger social and political developments in the U.S., and to the labor movement, embedding corporate governance in historical context.
\end{abstract}

Keywords: corporate governance, executive compensation, labor unions, say on pay, Dodd-Frank

*Corresponding author: Sanford M. Jacoby, Management History and Public Affairs, UCLA, LoS Angeles, USA, E-mail: sanford@ad.ucla.edu

C 2020 CONVIVIUM, association loi de 1901

Published online February 01, 2020 


\section{Table of contents}

1 Introduction

2 Economics of executive compensation

3 Pay proposals

4 Stock-based pay

5 Expensing options

6 Backdating

7 Say on pay and private orderings

8 Take it to Congress

9 Say on pay and Dodd-Frank

10 Pay ratios

11 Conclusions

Bibliography

\section{The Corporate Issue: A Tribute to Lynn Stout}

1. Why Lynn Stout Took Up the Sword Against Share Value Maximization, by Margaret Blair, https://doi.org/10.1515/ael-2020-0083.

2. Beating Shareholder Activism at Its Own Game, by Margaret Blair, https://doi.org/10.1515/ ael-2019-0040.

3. Ownership (Lost) and Corporate Control: An Enterprise Entity Perspective, by Yuri Biondi, https://doi.org/10.1515/ael-2019-0025.

4. The Shareholder Value Mess, by Jean-Philippe Robé, https://doi.org/10.1515/ael-2019-0039.

5. Executive Pay and Labor's Shares: Unions and Corporate Governance from Enron to DoddFrank, by Sanford M. Jacoby, https://doi.org/10.1515/ael-2019-0073.

6. How America's Corporations Lost Their Public Purpose, and How it Might be (Partially) Restored, by David Ciepley, https://doi.org/10.1515/ael-2019-0088.

7. The Contest on Corporate Purpose: Why Lynn Stout was Right and Milton Friedman was Wrong, by Thomas Clarke, https://doi.org/10.1515/ael-2020-0145.

8. Lynn Stout, Pro-sociality, and the Campaign for Corporate Enlightenment, by Donald Langevoort, https://doi.org/10.1515/ael-2020-0067.

\section{Introduction}

In the United States, the worlds of finance and organized labor spun in separate orbits for most of the twentieth century. They drew nearer at century's end, due in part to the magnetic force of swelling assets in union-influenced pension plans-multiemployer and public-employee plans-whose value reached over $\$ 3$ trillion by the late 1990s. It was a stark contrast to the plunge in union membership in America's private sector, once the heart of organized labor. Shaken by the decline, union leaders now prioritized growth in numbers to replenish the movement's fading power. Their strategies included the leveraging of stock held in pension plans and other finance-based tactics to pressure employers to 
remain neutral during union organizing campaigns. The labor movement and its pension plans often are ignored in discussions of corporate governance, executive pay, and regulatory responses to the financial crisis.

Often criticized for its hide-bound traditionalism, the U.S. labor movement responded energetically to financialization, riding the wave of stock market capitalism. After the beginning of the twenty-first century, union shareholders eclipsed public pension plans as shareholder activists. Placing limits on skyrocketing executive pay was labor's signature issue, one that public pension plans had shied away from. Union investors filed proposals seeking options expensing and say on pay, and occasionally they demanded that corporations report on the ratio of CEO pay to that of an ordinary worker. Union investors challenged the authority of CEOs and the directors who enriched them. Doing so drove a wedge between management and employees, reinforcing the claim that executive excess was shortchanging workers. If a union wanted to represent workers at the company, or already had a bargaining relationship, targeting executive pay could raise support for the union and/or embarrass management sufficiently that it would agree to tone down any anti-union behavior. We return to these issues below.

The focus on executive pay permitted tie-ins to broader social issues, especially income inequality. America's concern about inequality mounted during the 1990s and more rapidly after that. Among its causes was the plummeting of union density. Between 1973 and 2007, one-fourth to one-third of the growth in wage inequality was the result of union shrinkage. There also were hopes that shareholder activism would improve the performance of underfunded union pension plans.

There is a cottage industry of people who study inequality's causes. At the firm level, the widening pay gap between executives and the rank and file is a wellstudied subject. Executives figure prominently in the top 1 percent of the income distribution. Less often considered is the effect of shareholders on inequality. For the past thirty years, shareholders have received a growing share of valued-added paid as dividends and stock repurchases. The dubious claims of shareholder primacy - that shareholders own corporations and that their interests must be paramount-contributed to a reallocation of corporate profits among workers, owners, and managers. But the labor movement was slow to criticize mounting shareholder payouts, in part because this would have conflicted with the needs of its pension plans, and also because management was labor's traditional nemesis.

Shareholder activism was a slow slog, company by company, vote by vote. It required time-consuming meetings and costly proxy solicitations, usually to no avail since, in the end, directors and executives were free to disregard shareholder sentiment. On the other hand, government regulation was market-wide and possessed enforcement teeth. Getting government to take action depended on the ever-shifting balance of political forces, but shareholder activism was a 
prod. Writing about social movements of the 1970s such as Campaign GM (an effort to make General Motors more socially responsible) and anti-Apartheid protests demanding that institutions divest their holdings of companies doing business in South Africa, political scientist David Vogel observed, "The extent to which demands addressed to the corporation anticipate the substance of subsequent government regulation of business is quite striking."1

When attempts to change private orderings proved insufficient, labor and its friends in Washington sought to embed governance reforms in law. On several occasions during the 2000s, voluntarism anticipated and interacted with pay regulations formulated by the SEC and Congress, including those contained in the Dodd-Frank Act (2010), the main legislative response to the financial crisis. Governance reforms were adopted most widely when private activism was alloyed with legislation, politics being one place where labor still had sway.

As labor went on the offensive over executive pay, the Wall Street Journal opined that the issue was "perfect for galvanizing workers." The AFL-CIO released a study alleging that high levels of CEO pay were the result of "pervasive cronyism" between executives and board members. Compensation consultants were quick to challenge the report, with one of them implausibly stating that, inside the board room, "You don't see much cronyism." Bill Patterson of the AFL-CIO disagreed: "Companies are giving out stock options no matter what the CEO does or what the company does.” Patterson had a remarkable exchange with General Electric's CEO Jack Welch at GE's 1997 shareholder meeting. That year Welch's pay package was \$21.4 million, and he received 20,000 options on top of 2.2 million unexercised options. Patterson asked Welch, "My question to you is, do these options motivate you to bring more ideas, commit more value and more time to the growth of the company? ... Why stop at 320,000 shares?

\footnotetext{
1 Cited figures are from Lawrence Mishel, "Unions, Inequality, and Faltering Middle-Class Wages," Economic Policy Institute, Issue Brief no. 342, August 29, 2012; quote from David Vogel, Lobbying the Corporation (New York: Basic Books, 1978), 14. On unions and inequality, see Bruce Western and Jake Rosenfeld. "Unions, Norms, and the Rise in US Wage Inequality," American Sociological Review 76 (2011): 513-537; Christopher Kollmeyer and John Peters, "Financialization and the Decline of Organized Labor: A Study of 189 Advanced Capitalist Countries, 1970-2012” Social Forces 98 (2019): 1-30. For critiques of shareholder primacy, see Lynn A. Stout, "New Thinking on Shareholder Primacy," Accounting, Economics, and Law: A Convivium 2 (June 2012) at https://www. degruyter.com/downloadpdf/j/ael.2012.2.issue-2/2152-2820.1037/2152-2820.1037.pdf; Lynn Stout, The Shareholder Value Myth: How Putting Shareholders First Harms Investors, Corporations, and the Public (San Francisco: Berrett-Koehler Publishers, 2012); and Simon Deakin, “The Coming Transformation of Shareholder Value," Corporate Governance 13 (2005): 11-18.
} 
Why not double that? ... . Do the stock options motivate you?" "Absolutely," said Welch to laughter and applause from the audience. ${ }^{2}$

During the early 1900s and again during the 2000s, a new populism took hold in the United States, driven by the widening separation in pay and working conditions of ordinary workers from wealthy elites, including corporate executives. Many Americans felt that the system was rigged, and there was plenty of evidence to support them: the corporate pay scandals of the 2000s, beginning with options backdating, followed by Enron-era scandals, and ending with the financial crisis during which bankers' pay became a salient issue. This article is based on scrutiny of the historical record to establish the context in which actors tussled around executive pay. We identify actors and institutions, and embed them in politics and society. It's through historical accounts that we can study process, and separate conjunctural and structural change.

We begin in Part 2 with an examination of the economics of executive pay. This is followed by an overview of shareholder proposals to remedy defects in stock-based pay (Parts 3 and 4), including failures to expense options (Part 5) and unlawful backdating (Part 6) which had allowed executives to enrich themselves without shareholder knowledge or approval, sometimes unlawfully. Unions, as investors and political actors, were key players here. Their main focus, however, was say on pay: giving shareholders the right to vote on the board's recommended executive pay package (Part 7). It had been relatively uncontroversial in the United Kingdom but kicked off a storm of management opposition in the United States, even though the votes would be advisory. Say on pay found its way to Congress in the years preceding the 2008 financial crisis (Part 8) and then was enshrined in the Dodd-Frank Act (Part 9). When pay voting became prevalent, however, there were few of the predicted negative consequences. This is followed by a brief discussion of pay-ratio reporting (Part 10) an issue that the labor movement did not initially embrace. Conclusions round out the paper.

2 "Call to Action: Labor Has Discovered the Perfect Issue for Galvanizing Workers," Wall Street Journal, April 9, 1998. Patterson's questions were a throwback to the AFL-CIO’s 1991 "Model Guidelines," which supported stock-based incentive pay for managers but cautioned against providing additional stock compensation that might diminish the incentive effect. AFL-CIO Executive Council, "Model Guidelines for Delegated Proxy Voting Responsibility," February 1991; "Executive Pay: Do CEOs Get Paid Too Much," Congressional Quarterly Researcher 7, July 11, 1999, 603-4; "Unions Take Fight over CEO's Pay to Shareholders," Knight-Ridder Business News, April 11, 1999; "AFL-CIO Links Some Executives’ Big Paychecks to Cronyism,” Washington Post, April 10, 1998; Lucian Bebchuk and Yaniv Grinstein, "The Growth of Executive Pay,” Oxford Review of Economic Policy 21 (2005): 283-303. 


\section{Economics of executive compensation}

For decades, CEO pay was remarkably stable, standing at about the same inflation-adjusted level from the end of the Second World War through the 1970s. The stability mirrored that of the total income share flowing to the top brackets. A change occurred during the 1980s, when real total compensation of CEOs increased by 55 percent as did the size of top-income shares. After that, things accelerated dramatically: pay rose by 126 percent during the 1990 s and by 125 percent from 2000 to 2005. Stock-based compensation is only part of the story because CEO compensation grew twice as fast as share prices. ${ }^{3}$

Economists offer several explanations for the rise in executive pay. The firstoptimal contracting- asserts that CEOs are paid what they're worth. Economists like this idea: what is, is efficient. According to their account, changes in technology that began in the 1980s permitted the creation of a robust labor market for CEOs in which competition for scarce talent pushed up pay. Before the 1980s, allegedly, CEOs had skills that were specific to a single firm, which meant there was no incentive for other firms to hire them. Then their skills became fungible with the rise of MBA-CEOs whose accounting and finance skills could be used at any kind of company. Another strand relates rising CEO pay to firm size, as measured by capitalization. As size increased, CEO compensation went up because it was difficult to find people capable of managing large, complex organizations. A third is that the executive labor market originated in the changing power dynamics between shareholders and executives. Outsiders were preferable because they had no loyalty to the status quo. Competition for outsiders-"the search for saviors"-led to higher pay. ${ }^{4}$

3 Carola Frydman and Raven E. Saks, "Executive Compensation: A New View from a Long-Term Perspective, 1936-2005,” Review of Financial Studies 23 (2010): 2099-2138; Lawrence Mishel and Alyssa Davis, "Top CEOs Make 300 Times More than Typical Workers: Pay Growth Surpasses Stock Gains and Wage Growth of Top 0.1 Percent,” Economic Policy Institute, June 21, 2015; Bebchuk and Grinstein, "The Growth of Executive Pay."

4 Rakesh Khurana, Searching for a Corporate Savior: The Irrational Quest for Charismatic CEOs (Princeton, NJ: Princeton University Press, 2002); Carola Frydman and Dirk Jenter, "CEO Compensation,” working paper no. 16585, National Bureau of Economic Research, 2010; Alex Edmans and Xavier Gabaix, "Is CEO Pay Really Inefficient? A Survey of New Optimal Contracting Theories,” European Financial Management 15, no. 3 (2009): 486-96; Xavier Gabaix, Augustin Landier, and Julien Sauvagnat, "CEO Pay and Firm Size: An Update after the Crisis,” Economic Journal 124 (2014): F-60-F89; Steven N. Kaplan, “Are U.S. CEOs Overpaid?” Academy of Management Perspectives 23(2008): 5-20; Michael C. Jensen and Kevin J. Murphy, "Performance Pay and Top-Management Incentives," Journal of Political Economy 98 (1990): 225-264; Kevin J. Murphy, "The Politics of Pay: A Legislative History of Executive Compensation,” Marshall School of Business working paper no. FBE 1 (2011); Steven N. 
In the past, workers relied on collective bargaining to stabilize their share of value added. The portion of labor's share going to CEOs declined as part of the compression effect that unions have on within-firm pay. CEOs of unionized companies are paid less than comparable CEOs at nonunion companies, but as unions shrank, so did the size of the slice paid to nonmanagerial workers. Bargaining power-and pay- were further eroded by overseas outsourcing, an increase in part-time jobs, and use of outside labor contractors. Today, wages no longer track productivity. To whom do those productivity gains go? They go to shareholders and to CEOs. CEOs have made out quite nicely in recent years. They receive greater than the percentage increase in share prices on the upside; on the downside, their pay is rigid. There's nothing efficient here. ${ }^{5}$

Over time it became easier for CEOs to manipulate the pay-setting process to benefit themselves. Stock- based compensation offered myriad opportunities to game the system, and the scandals of 2000, 2002, and 2008 provided plenty of evidence of self-serving behavior. Other factors drove CEO rewards beyond what was competitively necessary: pay for "luck" rather than performance, an intentional lack of pay transparency, and compensation consultants who recommend to their clients that they pay their executives above average, producing a leapfrog effect. Spillovers from "bad" (overpaid relative to performance) to "good" firms occurred as "good" firms had to offer more to executives to meet the market. But what

Kaplan and Joshua Rauh, "Wall Street and Main Street: What Contributes to the Rise in the Highest Incomes?” NBER working paper 13270 (2007); Xavier Gabaix and Augustin Landier, “Why Has CEO Pay Increased So Much?” The Quarterly Journal of Economics123, no. 1 (2008): 49-100.

5 "Neither Rigged Nor Fair" The Economist, June 25, 2016; Lawrence Mishel and Natalie Sabadish, "CEO Pay in 2012 Was Extraordinarily High Relative to Typical Workers and Other High Earners,” Economic Policy Institute, June 26, 2013; K. J. Martijn Cremers and Yaniv Grinstein, "Does the Market for CEO Talent Explain Controversial CEO Pay Practices?" Review of Finance 18 (2013): 921-60; Mishel and Davis, “Top CEOs Make 300 Times More”; Qianqian Huang, Feng Jiang, Erik Lie, and Tingting Que, "The Effect of Labor Unions on CEO Compensation," Journal of Financial and Quantitative Analysis 52, no. 2 (2017): 553-82 ; John DiNardo, Kevin Hallock, and Jorn-Steffen Pischke, "Unions and Managerial Pay,” working paper no. 6318, National Bureau of Economic Research, 1997; Rafael Gomez and Konstantinos Tzioumis, "What Do Unions Do to CEO Compensation?" discussion paper 720, Centre for Economic Performance, London School of Economics, May 2006; Ian Dew-Becker and Robert J. Gordon, "Where Did the Productivity Growth Go? Inflation Dynamics and the Distribution of Income," National Bureau of Economic Research working paper no. w11842, 2005; Martin J. Conyon and Kevin J. Murphy, "The Prince and the Pauper? CEO Pay in the United States and United Kingdom," The Economic Journal 110, no. 467 (2000): 640-61; Lucian A. Taylor, "CEO Wage Dynamics: Estimates from a Learning Model,” Journal of Financial Economics 108, no. 1 (2013): 79-98. 
should CEOs receive? With so much of their compensation riding on luck and bargaining power, nobody really knows what they are worth. ${ }^{6}$

\section{Pay proposals}

Labor unions in the United States are not permitted to bargain over executive compensation. That leaves politics and shareholder activism as their options for weighing in on the issue. Union pension plans became shareholder activists in the 1990s and more so during the following decade, when they submitted an-ever growing number of shareholder proposals, which are voted on by shareholders but are merely advisory to the board of directors. Pay-related proposals mushroomed after the Enron-era scandals and jumped again in 2007. Union investors were responsible for the change; on average, they were more successful than other groups in obtaining majority support for their proposals. Nearly one out of four of them garnered a majority of "yes" votes between 2003 and 2007, whereas previously they had received a mere 2 percent. Labor chose its targets carefully: companies with governance defects and poor performance. Even when union investors had collateral interests related to obtaining new members, other institutional investors gave considerable support to union proposals. They cared more about immediate returns than any theoretical possibility that, if some of a company's employees joined a union, it would cut into funds that could have been used for shareholder payouts. ${ }^{7}$

6 "Pay Check," Economist, August 6, 2016; Lucian Bebchuk and Jesse Fried, Pay without Performance: The Unfulfilled Promise of Executive Compensation (Cambridge, MA: Harvard University Press, 2004); Gretchen Gavett, "CEOs Get Paid Too Much, according to Nearly Everyone in the World," Harvard Business Review, September 23, 2013; "Behind Big Dollars, Worrisome Boards," New York Times, April 9, 2006; Cremers and Grinstein, "Does the Market for CEO Talent?”; “Tax Savvy Execs Work for \$1, Get Paid Millions as Capital Gains,” Forbes, May 2, 2016; Taekjin Shin, "Fair Pay or Power Play? Pay Equity, Managerial Power, and Compensation Adjustments for CEOs," Journal of Management 42 (2016): 419-48; "House Committee Probes Executive-Pay Consultants," CFO.com, December 5, 2007; "How Big a Payday for the Pay Consultants?" New York Times, June 22, 2008; Carola Frydman and Dirk Jenter, "CEO Compensation," Annual Review Financial. Economics 2 (2010): 75-102. A comprehensive discussion of defects in executive pay setting is Bebchuk and Fried, Pay Without Performance.

7 Majority votes matter because, on average, a company's full implementation of all submitted pay proposals is only 5 percent, but, when a proposal receives a majority vote, full implementation rises to 32 percent. Yonca Ertimur, Fabrizio Ferri, and Volkan Muslu, "Shareholder Activism and CEO Pay,” Review of Financial Studies 24 (2011): 535-92. On labor's targets, see Andrew K. Prevost, Ramesh P. Rao, and Melissa A. Williams, "Labor Unions as Shareholder Activists: Champions or Detractors?,” Financial Review 47 (2012): 327-349; Ertimur, Ferri, and 
Who were the targets of labor's pay proposals? They were companies where CEOs collected high levels of pay and/or served as board chairs. A study of labor's pay activism found "no evidence of union-related motives," and companies were equally likely to implement compensation proposals from union investors as from public plans. Both were signs that labor was swimming in the shareholder mainstream. Occasionally, union investors selected firms with labor disputes, but the same study showed that this had no effect on the likelihood that other shareholders and proxy advisors would lend support. The only situation in which union investors incurred a voting penalty happened when the target firms' employees were affiliated with the union sponsoring the submission, not a common occurrence. ${ }^{8}$

The bull market of the 1990s left investors disinterested in executive pay. During those years, said Beth Young, "compensation had been considered a governance stepchild." CII's Ann Yerger said that her members might care more about executive compensation if the market were down but added, "Everybody's kind of fat and happy now." The situation changed shortly thereafter. Institutional Shareholder Services (ISS) now regularly backed pay proposals, whereas in the 1990s it had been less consistent in offering support. As always, public plans were chary of sponsoring pay proposals lest it appears that government was dictating what the private sector should do. Confidential meetings were a better way to go. ${ }^{9}$

Of the different compensation proposals offered during the 2000s, those demanding "say on pay," an advisory issue, were the single most popular type. Say on pay gave shareholders the right to vote on the board's pay recommendations, that is, greater voice in corporate governance rather than specific pay practices, although the latter was part of the mix. If we group all kinds of compensation-related proposals into categories, the largest by far involved stock-based pay. To eliminate various gimmicks, the proposals recommended

Muslu, "Shareholder Activism." The data on pay proposals and their sponsors is taken from Georgeson's Annual Corporate Governance Review (ACGR).

8 Ertimur, Ferri, and Muslu, "Shareholder Activism and CEO Pay," 566; Renneboog, Luc and Peter Szilagyi, "The Success and Relevance of Shareholder Activism through Proxy Proposals," European Corporate Governance Institute - Finance Working Paper, 275/2010, March 2010; Luc Renneboog and Peter Szilagyi, "The Role of Shareholder Proposals in Corporate Governance," Journal of Corporate Finance 17 (2011): 167-88; "Union Funds Champs of the Proxy Season," Pensions \& Investments (hereafter P\&I), February 5, 2007; Executive Excess: Annual CEO Compensation Survey, 2003-2007 (Washington, DC: Institute for Policy Studies).

9 Interview with Beth Young, July 2008, New York City; "Heads I Win, Tails I Win: More Companies Offer Bonus Payments That Aren't Tied to Performance," Wall Street Journal, April 6, 2000. 
options indexing, longer time periods for cashing options, and eliminating options entirely and replacing them with other types of stock-based pay such as performance-based units and restricted stock.

Disclosure of executive compensation drew relatively few proposals and few votes. The picture changes if one classifies options expensing as a type of disclosure. Then there were "social" pay proposals, a potpourri of ideas for tying executive pay to nonstock criteria such as employee satisfaction, environmental performance, and downsizing (cutting CEO pay after mass layoffs), but these were much more likely to come from socially responsible investors than union funds. There were two other items of note: so-called commonsense pay plans and pay for superior performance plans, both developed by the Carpenters Union. ${ }^{10}$

\section{Stock-based pay}

Stock options were not a new practice, but they were uncommon until after the Second World War. The Revenue Act of 1950 sweetened the tax treatment of qualified stock plans and caused an uptick in their usage. One of the earliest critics was the AFL-CIO’s Industrial Union Department, which in 1959 issued a report called "The Stock Option Scandal.” Stock options, said the report, "provide tax-privileged, risk-free profit opportunities unrelated in any meaningful way to executive performance and unchecked by effective stockholder control." These were prescient words, all the more so given that stock options counted for less than 5 percent of CEO compensation during the 1950s.

The idea of compensating executives with stock-based pay instead of salaries received strong support during the 1980s, when American industrial companies were struggling to compete in global markets. Financial economists such as Eugene Fama and Michael Jensen alleged that America's industrial problems were the result of executives failing to act in the interests of the corporation's principals, its shareholders. Either they were pursuing their own interests, which included riskaversion (the quiet life), or they were giving undue attention to stakeholders whose interests were unrelated to share-price maximization, such as employees and communities. Payment in cash, they said, would not wake executives from their quiet life because the money was risk-free. Economists Michael Jensen and Kevin J.

10 Yaniv Grinstein, David Weinbaum, and Nir Yehuda, "Perks and Excess: Evidence from the New Executive Compensation Disclosure Rules,” working paper no. 04-09, Cornell University, Johnson School Research Paper Series, 2008. The easiest way to track pay proposals over time is through AGCR, which breaks out non-withdrawn pay proposals by type, sponsor, and voting outcome. 
Murphy said in 1990 that tying executive pay to stock prices and firing CEOs if they failed to raise them were "the most effective tools for aligning executive and shareholder interests." Institutional investors seconded the idea. Jon Lukomnik, the deputy comptroller for New York City's pension plans, said in 1995 that "shareholders just don't own a piece of paper but actually own the company. The whole thing is you don't want management to have a different set of initiatives financially than the shareholders have. You want to align the business of managers with shareholders so they both prosper together."11

Stock options, as intended, caused CEOs to take bolder steps but there were unintended consequences. Options delivered erratic corporate performance-big gains and big losses-with the losses exceeding the gains. It may explain why companies whose CEOs received options worth more than those of comparable firms experienced unexpectedly low stock returns. Related to risk is the finding stock options were associated with product safety problems because they "promote a lack of caution in CEOs." Although options repeatedly were touted as a mechanism for aligning managers and shareholders, they were like other incentive-pay schemes in that recipients eventually figured out how to game them. Law professors Lucian Bebchuk, Jesse Fried, and David Walker found that misuse of options was rife, and that they were associated with earnings manipulation and corruption.

That executives used options to extract rents is evident in their design: a host of clever features such as failing to index a company's stock gains to performance of its peers, offering in-the-money options (guaranteed payoff), reloading (breaking the pay-performance link by protecting options losses), hedging the company's own stock, spring loading (timing an options grant to precede positive news), repricing (replacing underwater options with new, above-water ones), and other tricks that were difficult to discern. The lack of transparency was intended, not accidental, something that the AFL-CIO first had flagged in its 1959 report: "The average person is caught in a maze if he attempts to obtain some idea of the value of stock options granted to specific individuals." But even if options reduced the relative size of rents going to shareholders, they helped erode vestiges of managerialism. Said Damon Silvers of the AFL-CIO, "The managerial class gave up resisting the financial players and realized that it was better to play along with

11 Industrial Union Department, AFL-CIO, The Stock Option Scandal (Washington, DC: 1959), 23; Michael C. Jensen and Kevin J. Murphy, “CEO Incentives - It’s Not How Much You Pay, But How,” Harvard Business Review 68, no. 3 (1990): 138-53; Eugene F. Fama and Michael C. Jensen. “Agency Problems and Residual Claims," Journal of Law and Economics 26 (1983): 327-349. For a cogent criticism of agency theory as applied to corporate governance, see

Iman Anabtawi and Lynn Stout, "Fiduciary Duties for Activist Shareholders," Stanford Law Review 60 (2007): 1255-1308. Lukomnik in "Holders Put the Screws to Wooden Performers," Footwear News, November 27, 1995. 
them. You got very rich by playing along with them ... and stock options were a big part of that change."12

\section{Expensing options}

One reason stock options flowed like water during the 1990s and early 2000s was that they were not reported on a company's books, thus overstating earnings. At WorldCom, earnings would have been 30 percent less in 2000 had options been expensed. Options also reduced taxes, at least for NASDAQ and S\&P 100 companies. Companies were permitted to take a tax deduction for employees gains when they exercised their options. Heavy users-high-tech firms like Microsoft and Cisco Systems-erased all or most of their federal taxes by failing to expense. Stock options almost certainly would have been less widespread had expensing been required. ${ }^{13}$

12 William Sanders and Donald C. Hambrick. "Swinging for the Fences: The Effects of CEO Stock Options on Company Risk Taking and Performance, “ Academy of Management Journal 50 (2007): 1055-1078; Michael J. Cooper, Gulen, Huseyin and Raghavendra Rau, "Performance for Pay? The Relation Between CEO Incentive Compensation and Future Stock Price Performance," SSRN working paper 1572085, November 1, 2016; Adam J. Wowak, Michael J. Mannor, and Kaitlin D. Wowak, "Throwing Caution to the Wind: The Effect of CEO Stock Option Pay on the Incidence of Product Safety Problems," Strategic Management Journal 36 (2014): 1082-92; Lucian Bebchuk, Jesse Fried, and David Walker, "Managerial Power and Rent Extraction in the Design of Executive Compensation," University of Chicago Law Review 69 (2002): 751-55; Bebchuk and Fried, Pay without Performance; Jared Harris and Philip Bromiley, "Incentives to Cheat: The Influence of Executive Compensation and Firm Performance on Financial Misrepresentation,"Organization Science 18, no. 3 (2007): 350-67; Lin Peng and Ailsa Roell, "Executive Pay and Shareholder Litigation," Review of Finance 12, no. 1 (2008): 141-84; "Bush Failed to Stress Need to Rein in Stock Options,” Wall Street Journal, July 11, 2002; Edmans, Gabaix, and Jenter, "Executive Compensation”; interview with Damon Silvers, March 2007, Washington, DC.

13 "Bush Failed"; Sanford M. Jacoby, "For More Honesty with Stock Options," Christian Science Monitor, July 29, 2002. Graham and his colleagues explain that, "Unlike other forms of compensation, stock options are not typically reflected in pretax income or in deferred taxes. In terms of pretax income, options are generally not considered an income statement expense, and firms that opt not to expense stock options also do not reduce tax expense on the income statement to reflect the effect of option deductions. Further, unlike many book/tax differences, the effect of options is not captured in deferred taxes because the difference between tax and book income never reverses. As a result, a firm can consistently report high tax expense (on financial statements) and never pay any taxes (on tax returns). Prior research has typically used income statement data to infer taxable income and thus ignored option compensation deductions for the majority of firms (because most firms do not expense options).” John R. Graham, 
Beginning in the mid-1980s, when options were starting to catch on, the Financial Accounting Standards Board (FASB), the US accounting-standards setter, considered requiring companies to expense stock options to show the liabilities they were carrying on their books. The issue came to head in 1993, when FASB released the draft of an expensing plan. Democratic Senator Carl Levin of Michigan offered a bill making expensing mandatory if companies took a tax deduction when options were cashed. The business community, with high tech in the lead, formed a united front against expensing.

The 1990s was an era of boundless enthusiasm for high tech, and Congress mostly supported that fervor. Democrats from tech-heavy states in New England and California led the opposition to expensing. Senators Joseph Lieberman (DCT) and Ed Markey (D-MA) savaged the FASB proposal. By a lopsided vote of eighty- eight to nine, the Senate passed a nonbinding resolution asking FASB to drop its expensing project, so it did. Lieberman called this "a great victory for American business and workers," while Levin said that "honest accounting lost out to the pressure of the rich and powerful." In retrospect, Levin was closer to the truth. An accounting professor at Columbia University subsequently judged Lieberman's intervention as the first step on "the slippery slope that got us mired in the Enron swamp." 14

The California Public Employee Retirement System (CalPERS) the giant public pension plan, was susceptible to lobbying from the state's technology and venture-capital companies, was firmly against expensing. It pressed the national association of public pension plans, the Council of Institutional Investors to remain neutral on the issue. CalPERS preferred to leave the issue to advisory votes by shareholders. The AFL-CIO's Karen Ignani, director of employee benefits, asked FASB and CII to adopt a compromise according to which companies would not have to expense their options but would have to separately list on their financial statements their present value and the impact on stock dilution. Under pressure from union investors, most CII members supported the compromise. But opposition from CalPERS and from Cll's

Mark H. Lang, and Douglas A. Shackelford. "Employee Stock Options, Corporate Taxes, and Debt Policy,” Journal of Finance 59 (2004): 1589.

John R. Graham, Mark H. Lang, and Douglas A. Shackelford. "Employee Stock Options, Corporate Taxes, and Debt Policy,” Journal of Finance 59 (2004): 1589.

14 William Greider, "Not Wanted: Enron Democrats," The Nation, April 8, 2002; "FASB Caves in on Stock Options," Practical Accountant, February 1, 1995. FASB sets U.S. GAAP standards for public companies. Although it is a private organization, it is designated by the government's Securities and Exchange Commission to have authority in this area. The blending of public purpose and private administration is a potential source of conflict with accountability and transparency, as became clear after Enron failed 
corporate pension funds kept CII from endorsing it. Three years later, Levin, this time together with Republican Senator John McCain (AZ), offered another bill to expense stock options. But this effort went nowhere; by then, the economy was in overdrive and executive compensation less of a concern. ${ }^{15}$

Come Enron, and expensing again was on the agenda. Senators Levin and McCain, joined by new players like Representative Barney Frank (D-MA), reintroduced their expensing bill. Republicans were dead set against it; instead, the GOP created the Senate Republican High-Tech Taskforce, with the express purpose of heading off expensing. Working with them was the International Employee Stock Options Coalition, a lobbying group composed of venturecapital and technology companies. The party line was that expensing was technically unfeasible; there was no way to calculate the present value of option liabilities. Opposition to expensing included a phalanx of heavy hitters: President George W. Bush, Harvey Pitt of the SEC, and the nation's two main business associations-the U.S. Chamber of Commerce and the Business Roundtable. $^{16}$

On the other side were prominent business figures like Warren Buffett and Alan Greenspan, who noted that business people were not any greedier than in the past but that stock options had given them "avenues to express greed." A study by the Boston Consulting Group found that the value of stock options granted to companies guilty of options-related fraud was 800 percent greater than those given to CEOs of comparable firms: "Nothing correlated so strongly with corporate fraud as the value of stock options-not the standard of the firms' governance, nor analysts' inflated expectations about their earnings, nor egoboosting stories about their CEOs in the press."17

15 Andrew K. Prevost and John D. Wagster, "Impact of the 1992 Changes in the SEC Proxy Rules and Executive Compensation Requirements," unpublished paper, September 1999; "Accounting Board Yields on Stock Options," New York Times, December 15, 1994; Harlan Wells, "U.S. Executive Compensation in Historical Perspective," in Research Handbook on Executive Compensation, ed. Randall S. Thomas and Jennifer G. Hill (Cheltenham, UK: Elgar, 2012), 4157; “Council Toughens Stance,” P\&I, February 21, 1994.

16 "Business Lobby Seeks to Limit Investor Votes on Options," New York Times, June 6, 2002. Despite the hoopla about secretaries in high-tech companies becoming rich from their stock options, in fact, 75 percent of stock options went to a company's top five executives, and more than half the remainder went to the next fifty managers. Only three million workers- about 2 percent of the U.S. labor force-were granted stock options, and they received a relative pittance. Roger Lowenstein, Origins of the Crash: The Great Bubble and Its Undoing (New York: Penguin, 2004), 45.

17 "The Campaign to Keep Options off the Ledger," Bloomberg News, July 14, 2002; Lucian Bebchuk, "Insider Luck and Governance Reform," presentation for Capital Matters, May 2007; Boston Consulting Group in "Fat Cats Turn to Low Fat," The Economist, March 3, 2005. 
Sarbanes-Oxley (SOX) contained a few provisions regulating stock options, such as rapid disclosure. The law created a Public Corporation Accounting Oversight Board, in response to criticisms that FASB, a private organization, was too close to the financial industry. But fierce opposition from business kept expensing out of the act. Labor was furious about that omission. On the day that the law went into effect, the AFL-CIO held a rally to kick off a nationwide campaign, "No More Business as Usual.” Hundreds of union members gathered in front of the New York Stock Exchange to listen to AFL-CIO president John Sweeney denounce Enron's ex-executives for cashing their options as the company went under. "They are thieves and they are stealing our hopes, stealing our dreams, and stealing our future," he declaimed. In a press release, Sweeney blamed stock options for driving up executive compensation "to an obscene 410 times average workers' pay.” However, compared to his rhetoric, Sweeney’s recommendations were blandly technocratic. He told the rally that the number-one item on his agenda was expensing. The other was to prohibit executives from selling shares in their firm while in office, which, he said, would remove incentives for them to pump up their company's stock. ${ }^{18}$

Congress returned to the executive compensation issue several months after SOX became law. The Senate Commerce Committee, chaired by John McCain, convened hearings in May 2003. The Arizona senator, by now a longtime critic of top-level overcompensation, was particularly incensed by the airline industry, which had been paid close to $\$ 4$ billion from the government to tide it over the drop in airline travel following 9/11. The subsidy had been contingent on fixing what McCain called "insulting" executive pay packages, yet the airlines had failed to rein in compensation. The hearings delved into a variety of other topics, including Jack Welch. Welch had been invited to testify but did not appear, nor did other highly paid CEOs like Michael Eisner and Leo Mullin (Delta Airlines). McCain, sounding even more spirited than Sweeney, warned that the United

18 "How Congress Rode a Storm to Corporate Reform," Washington Post, July 28, 2002; "AFLCIO Head Calls for Grass-Roots Campaign against Corporate Greed,” AP Newswire, July 30, 2002; "Statement by AFL-CIO President John J. Sweeney on the Need for New Rules to Ensure Corporate Accountability," PR Newswire, July 9, 2002. During the Congressional hearings leading up to Sarbanes-Oxley, the AFL-CIO's Damon Silvers testified that "[a]nyone familiar with the political pressures brought to bear on FASB around accounting for executive stock options in the mid-1990's, not to mention the decade long paralysis on SPE [Special Purpose Entities, a major issue at Enron] accounting knows that FASB is too open to pressures from issuers and those beholden to issuers." After SOX's passage, Silvers was appointed to the PCAOB's Standing Advisory Group and its Investor Advisory Group. Silvers quoted in Donna M. Nagy, "Playing Peekaboo with Constitutional Law: The PCAOB and its Public/Private Status.” Notre Dame Law Review, 80 (2004): 988. 
States was "returning to a second Gilded Age" and that stock option misdeeds "give capitalism a bad name."19

Damon Silvers, associate counsel for the AFL-CIO, was one of those who did appear, providing wide-ranging testimony. He was a product of labor's financial turn, a graduate of Harvard's business school and its law school. Playing to McCain, he noted that, after 9/11, American Airlines had failed to disclose an executive pay plan that included a $\$ 41$ million payment to protect executive pensions in case of bankruptcy. He said that the timeframe for granting options was too short and led to risky decisions that hurt the interests of long-term investors like pension funds. FASB and the SEC had the power to do something about executive compensation, Silvers asserted, but "they need the support of Congress." In light of the business community's campaigns, he stressed that the accounting board had to have its independence protected so it could proceed with what it had been trying to do for twenty years. However, a greater issue was at stake than expensing, he contended: "Our markets will be damaged if after the events of the last two years it appears that our accounting standards are still being held hostage to the very political dynamics that prevented effective regulation in the 1990s."20

Business lobbying against a FASB rule remained intense. The International Employee Stock Options Coalition collected signatures from more than forty members of Congress, including California representatives from both sides of the aisle, and sent them to FASB in January 2003. The coalition brought prominent executives to Washington to make personal visits to members of Congress. They included Oracle's Larry Ellison, another CEO who had thumbed his nose at McCain's committee. Representatives David Dreier (R-CA) and Anna Eshoo (DCA) co-sponsored a bill to delay any FASB rule until the completion of a threeyear study of expensing. In November, Senator Michael Enzi (R-WY), a former accountant, introduced yet another bill to stave off an FASB standard, this one requiring that expensing be limited to a company's top-five executives. With a touch of hyperbole, Enzi said a FASB rule would kill entrepreneurial activity in the United States. Not to be outdone, John Doerr, the doyen of the venture-

19 "Despite Recession, Perks for Top Executives Grow," Los Angeles Times, February 1, 2002; "Corporate Reform, Back on the Front Burner," National Journal, March 1, 2003; "Excessive Executive Pay Eroding Investor Confidence,” Associated Press, May 20, 2003; CEO Compensation in the Post-Enron Era: Hearing be!ore the Committee on Commerce, Science, and Transportation, 108th Cong., 1st Sess., May 20, 2003 (Washington: U.S. GPO, 2006). The association between commercial airplanes and the destruction of the World Trade Center caused a sharp drop in passenger travel. The federal government responded with loans and short-term assistance to the commercial airline industry.

20 CEO Compensation, 15-17; "Investors Grow Restive over Lavish Boardroom Pay." 
capital industry, said to FASB's chairman, “I don’t think there could be a worse time in America's economic history to adopt such a policy."21

In the midst of this back and forth, Microsoft broke ranks with an electrifying announcement: it would abandon stock options for a mix of time- and performance-based stock grants. The company had been preceded one year by Coca-Cola, but Coke was not from the tech world, nor was it nearly as influential as Microsoft. Following the announcement, Richard Trumka of the AFL-CIO sent letters to twelve major companies, including Intel and Cisco, urging them to follow suit. Sounding more like the attorney he was than a tough- talking union chief, Trumka wrote, "I strongly encourage you to expense all equity compensation including previously granted stock options, and to grant performancevesting restricted stock to senior executives instead of stock options." Bill Patterson labeled the Microsoft decision "a defection" and "the beginning of the end, though not the end" for unexpensed options. ${ }^{22}$

On a parallel track, union investors offered numerous shareholder proposals to compel expensing. Companies successfully bid the SEC to block them-as when National Semiconductor said that a Carpenters' proposal was an accounting-related and not pay-related matter and therefore covered by the ordinary business exclusion. At the end of 2002, the SEC reversed course and deemed expensing "an important social policy issue," hence, free from the exclusion. Ed Durkin immediately announced that his building-trades coalition planned to submit over a hundred proposals and "create momentum" to prod Congress and FASB to act. "Shareholder proposals," he said, "provide an opportunity to weigh in while politicians are waffling."

Over 150 expensing proposals were filed in 2003 and 2004; of these, 107 made it to a vote. Over 90 percent of the proposals came from union investors, most of them in Durkin's coalition, and they received an average vote of 49 percent. Support reached 90 percent at Starwood Hotels and 79 percent at Fluor. After the vote, Fluor responded by immediately beginning to expense options. Like other companies at this point, it could see the handwriting on the wall. Fabrizio Ferri and Tatiana Sandino, accounting professors at Columbia and USC, respectively, found that the mere submission of an options-related proposal in

21 "Corporate Reform, Back on the Front Burner”; “Congress, FASB in Stock Option Flap," CFO. com, June 6, 2003; "This Options- Expensing Bill Is No Reform,” Business Week, November 25, 2003; Doerr quoted in Michael Liedtke, "Tech Industry Challenges Reform," Los Angeles Times, May 20, 2003.

22 "Coke to Report Options as an Expense," New York Times, July 15, 2002; “Tarnished Gold: Microsoft Ushers Out Era of Options," Wall Street Journal, July 9, 2003; “AFL-CIO Asks Others to Follow Microsoft on Options," Reuters, July 9, 2003. 
2003 was associated with an 11 percent increase in the likelihood of a company's voluntarily choosing to expense. When proposals obtained majority votes at Fortune 500 companies, they were followed by an average decrease in CEO compensation of $\$ 2.3$ million, a significant amount. ${ }^{23}$

After FASB issued a draft expensing proposal, Cisco and Intel prodded their employees to swamp the board with antiexpensing letters. Cisco executives knew that, if they had to expense options, earnings would be cut by over a third. On the other side, the AFL-CIO created a form letter stating that executives should be "ashamed for trying to hide the cost of stock options" and put it on the Paywatch site. The AFL-CIO was one of the founders of RestoretheTrust.com, a forty-member association of pension funds and other institutional investors that earlier had lobbied for Sarbanes-Oxley. The group had a form letter sent by nearly one thousand people that excoriated unexpensed options and the "exorbitant pay packages" that resulted from them. ${ }^{24}$

In the background was the steady drumbeat of corporate scandals. The SEC sued HealthSouth in 2003 for falsifying \$2.7 billion in profits. The Justice Department indicted Richard Scrushy, the company's CEO, for money laundering, securities fraud, and other charges. This was one of the few criminal cases ever pursued for violations of Sarbanes-Oxley. Shareholders filed lawsuits charging Scrushy with insider trading connected to sale of his stock options. That same year a cocky Jack Welch got his comeuppance after his divorce proceedings revealed a secret severance package that left General Electric on the hook for a luxury apartment, regular flower deliveries, and food service staff, among other eye-opening perks. Even the SEC criticized GE for failing to disclose the details of Welch's retirement deal. In contrast to the shareholder meeting where Bill Patterson drew hoots of derision from other investors, the 2003 meeting saw

23 "Shareholders Have the Floor," Boston Globe, January 2, 2003; "Joint Effort: Union Funds Using Proxy Resolution as Lobbying Tool,” P\&I, June 9, 2003; interview with Ed Durkin, April 2008, Washington, DC; Fabrizio Ferri and Tatiana Sandino, "The Impact of Shareholder Activism on Financial Reporting and Compensation: The Case of Employee Stock Option Expensing," The Accounting Review 84 (2009): 433-66. Durkin quoted in Phyllis Plitch, “Teamsters Enter Options War with Battle Against Tech Co," Dow Jones News Service, October 17, 2002.

24 "Cisco and FASB: Options Showdown," CFO.com, May 24, 2004; "Letter Campaigns Try to Sway FASB on Option Expensing,” Dow Jones Newswires, May 18, 2004; “Group of Big Pension Funds, Unions, Urges Option Expensing,” Dow Jones Newswire, May 19, 2004; FASB Proposals on Stock Option Expensing: Hearing be!ore the Subcommittee on Commerce, Trade, and Consumer Protection o! the Committee on Energy and Commerce, U.S. House of Representatives, Serial 10899, July 8, 2014; Fabrizio Ferri, Garen Markarian, and Tatiana Sandino, "Stock Options Expensing: Evidence from Shareholders' Votes,” European Accounting Association Annual Congress, Goteborg, DE, 2005. 
one shareholder stand up and say, "What we did for Jack Welch was absolutely disgusting." 25

In the wake of repeated scandals, investors realized that they'd been scammed. Michael Jensen, an early and influential enthusiast, recanted his faith: "I recommend that a company never again issue another typical standard executive stock option. The vast increase in the use of options in managerial compensation plans in the last decade does not suffice to identify managers' interests with those of their stockholders and with that of society." Paul Volcker took a similar position, blaming fixed-price options for a "capricious element" and recommending that they be "strongly discouraged for public companies." FASB finally adopted an expensing rule in December 2004. ${ }^{26}$

There then occurred a dramatic reversal in the popularity of options, from a weight of 49 percent in CEO compensation in 2000 to 12 percent in 2016, though they were replaced by other lucrative types of stock-based pay. One group, however, failed to recoup losses from the ebbing of stock options: nonexecutive employees. During the NASDAQ boom, stock options had been liberally distributed, but because expensing raised the real cost of options, fewer employees now received them. ${ }^{27}$

25 "HealthSouth Founder Is Charged with Fraud," Washington Post, November 5, 2003; "Former HealthSouth CEO, Richard Scrushy, Gets Prison Sentence Reduced," Forbes, January 26, 2012; "GE Executive Pay under Spotlight at Annual Meeting," Reuters, April 22,

2003; "Investors Grow Restive"; "GE Settles with SEC over Welch Retirement Perks," Reuters, September 23, 2004.

26 "Why the Get-Rich-Quick Days May Be Over," Wall Street Journal, April 14, 2003; Michael C. Jensen, "How Stock Options Reward Managers for Destroying Value and What to Do About It," Harvard Business School, working paper No. 04-27, April 2001; Volcker in Conference Board, Commission on Public Trust and Private Enterprise (New York: The Conference Board, 2003), 13; Miller in "Weighing the Options," Business Mexico, November 1, 2002; David F. Larcker and Brian Tayan, "Union Activism: Do Union Pension Funds Act Solely in the Interest of Beneficiaries?” Rock Center for Corporate Governance Stanford University, working paper CGRP-30 (2012).

27 L. D. Brown and Y. Lee, "The Impact of SFAS 123R on Changes in Option-Based Compensation,” SSRN working paper 930818 (2007); Equilar, 2016 CEO Compensation Pay Trends (Equilar, Redwood City, CA: 2016); “Citigroup Payouts of Chiefs Irk Holders,” Wall Street Journal, August 25, 2006; Jacob S. Hacker and Paul Pierson, "Winner-Take-All Politics: Public Policy, Political Organization, and the Precipitous Rise of Top Incomes in the United States," Politics and Society 38 (2010): 152-204; Douglas L. Kruse, Joseph R. Blasi, and Rhokeun Park, "Prevalence, Characteristics, and Employee Views of Financial Participation in Enterprises," ed. Kruse, Blasi, and Richard B. Freeman, Shared Capitalism at Work (Chicago: University of Chicago Press, 2010), 50. 


\section{Backdating}

No sooner had expensing become law than another problem arose: options backdating. Backdating occurs when an option's grant date is reset to an earlier date. Doing this minimizes the risk associated with a falling share price and raises the option's value. While not unlawful per se, if it is not disclosed and approved by shareholders, it can violate accounting and securities laws. Backdating also overstates net income. If backdating is unreported but subsequently discovered, a financial restatement is required, which reduces previous profits. A study by Erik Lie at the University of Iowa found that backdating had led to executives receiving "billions of [illegitimate] dollars." The Wall Street Journal reported Lie's findings in a March 2006 story that rocked the business world. The Journal created a website revealing companies under scrutiny by the Justice Department and the SEC. ${ }^{28}$

Of nearly eight thousand companies studied by Lie, almost 30 percent-more than two thousand from all industries, not only tech-had not reported backdated options granted between 1996 and 2005. Most companies were forced to restate earnings. A few had credit downgrades and were temporarily delisted. Several CEOs were indicted by the Justice Department. Some of the companies investigated for backdating would later be implicated in the subprime mortgage meltdown. In fact, sixteen months after a shareholder sued Lehman Brothers for manipulating grant dates, the company declared bankruptcy. ${ }^{29}$

In 2006, the SEC circulated a draft proposal to limit backdating and other compensation problems through enhanced disclosure in proxy statements, annual reports, and registration statements. The rules would require that most of the disclosure be written in plain English. But the proposal left many people dissatisfied. Pressure on the SEC to take a tougher stance came in various forms, including shareholder proposals from union investors. The Electrical Workers'

28 Erik Lie, “On the Timing of CEO Stock Option Awards," Management Science 51 (2005): 80281; Randall A. Heron and Erik Lie, "What Fraction of Stock Option Grants to Top Executives Have Been Backdated or Manipulated?" Management Science 54 (2009): 513-25; "The Perfect Payday,” Wall Street Journal, March 18, 2006; "Perfect Payday: Options Scorecard,” Wall Street Journal, http://online.wsj.com/public/resources/documents/info-optionsscore06-full.html 29 "Authorities Probe Improper Backdating of Options," Wall Street Journal, November 11, 2005; Yonca Ertimur, Fabrizio Ferri, and David A. Maber, "Reputation Penalties for Poor Monitoring of Executive Pay: Evidence from Option Backdating," Journal of Financial Economics 104 (2012): 118-44; "Options Scandal in U.S. Set to Grow Further," Bloomberg News, August 4, 2006; "Silicon Valley Was Calming Down. Now an Options Scandal," New York Times, July 22, 2006; "Lehman Sued over Alleged Backdating,” Wall Street Journal, April 14, 2007; Bebchuk, “Insider Luck and Governance Reform.” 
(IBEW) pension plan demanded longer holding periods for stock options, the AFL-CIO sponsored proposals asking that vesting be prohibited until performance criteria were met, and LongView sought specific grant dates and filed backdating resolutions at nine companies.

To keep the pot boiling, the AFL-CIO posted a form letter on Paywatch demanding that the SEC require companies to disclose the formulas used to calculate annual bonuses and stock options. More than fifteen thousand site visitors sent letters to the agency, this out of a total of twenty thousand public comments, more than for any other SEC rule in history. Large public pension plans-among them CalSTRS, CalPERS, and the New York state and city funds-as well as Cll and LongView, criticized the SEC's proposal because it would shift responsibility for preparing compensation reports from the board's compensation committee to the CEO and CFO. The SEC rolled out its final disclosure regulations in July 2006, the biggest change in pay reporting since the 1930 s. $^{30}$

Changes were on the way at the SEC. Business had long been unhappy with William Donaldson, the SEC's chief since 2002. A former investment banker and corporate liberal, Donaldson took his mandate seriously, too seriously for the business community. He came under fire from a broad group of critics: the U.S. Chamber of Commerce, Treasury Secretary John Snow, Federal Reserve Chairman Alan Greenspan, and others. Donaldson, said Snow, had engaged in "regulatory overreach." With so much opposition, the SEC director "quit" in June 2005. Replacing him was Christopher Cox, a conservative former House member from Southern California. Despite the SEC's new backdating rule, under Cox the pace of investigation was lethargic. Few executives were indicted, and only two went to prison, both from high-tech companies in California. ${ }^{31}$

30 "Funds Urge SEC to Rethink Pay-for-Performance Disclosures," Dow Jones Newswires, April 12, 2006; "Executive Pay Debate Highlights Minimal Power of Shareholders," Wall Street Journal, February 7, 2006; "Stock Option Timing: The Scrutiny Intensifies, Mondaq Business Briefing, July 31, 2006; testimony of Brandon J. Rees, Protecting Investors and Fostering Efficient Capital Markets: Hearings before the Committee on Financial Services, U.S. House of Representatives, 109th Cong., 2nd Sess. (May 25, 2006); Cornish Hitchcock (attorney for Amalgamated Bank) to SEC, April 10, 2006, courtesy of Scott Zdrazil; "Shareholders to Target Options Backdaters in 2007 Proxies” Dow Jones Newswire, October 26, 2006; ACGR, 2006, 2007; "Perfect Payday: Stock Option Practices Newest in Long Line of CEO Pay Abuses," AFL-CIO NOW, June 30, 2006; "SEC Issues Rules on Executive Pay, Options Grants," Wall Street Journal, July 27, 2006; “Options Scandal in U.S. Set to Grow Further.” The SEC disclosure rules filled over four hundred pages and can be found at https://www.sec.gov/rules/final/2006/33-8732a.pdf. For a summary, see "SEC Votes to Adopt Changes to Disclosure Requirements Concerning Executive Compensation and Related Matters,” SEC Press Release 2006-123, July 26, 2006.

31 "Business Leaders Welcome Tighter Rules but Now Some Claim the Reforms Are Doing More Harm than Good," Financial Times, June 1, 2004; "Donaldson Ends SEC Tenure," Wall Street 
Another knock on Cox was his dark-of-the-night revision of stock-option rules, a change put in place on the Friday before Christmas 2006. It permitted companies to spread the cost of a grant over several years instead of counting its value during the issuance year. Shareholder activists were furious. The Laborers, with $\$ 30$ billion in its Taft-Hartley plan, said the change was all about optics; it would "make the numbers look smaller than they really are." CalPERS, CalSTRS, Cll, TIAA-CREF, and the AFL-CIO loudly complained to the SEC. Barney Frank blasted Chairman Cox for offering a "Christmas eve gift to corporate America." On the other hand, the U.S Chamber of Commerce praised the revision, and even President Bush commended Cox for "making sure that the regulatory burden is not oppressive." 32

\section{Say on pay and private orderings}

The SEC's new regulations emphasized disclosure, requiring that annual reports contain tables showing stock returns versus an appropriate benchmark. Backdating was addressed with a provision that companies publicize grant dates and stock prices on those days. But sunlight doesn't always disinfect. Some companies subsequently reported the required data in what the Washington Post called "gobbledygook." The newspaper asked three compensation consultants to study Disney's annual report and indicate what Disney's CEO received. The figures ranged from $\$ 21$ million to $\$ 31$ million to $\$ 51$ million. Disclosure, said Damon Silvers, “doesn't change the underlying dynamics to make boards more accountable to investors.” To get accountability, activist

Journal, June 2, 2005; "SEC Chairman Makes Exit," Globe and Mail (Canada), June 2, 2005; "Donaldson: The Exit Interview," New York Times, July 23, 2005; "Labor Unions Urge Members to Oppose Cox as SEC Chairman,” Dow Jones Newswire, July 12, 2005. A careful study finds that the SEC over time reduced the intensity of its backdating investigations and became less likely to scrutinize individual executives. Stephen J. Choi, Anat Wiechman, and A. C. Pritchard, "Scandal Enforcement at the SEC: The Arc of the Option Backdating Investigations," American Law and Economics Review 15 (2013): 542-77.

32 "Congress Is Urged to Hold Off Acting on Options and Pay," New York Times, September 7, 2006 "Investor Outcry over Exec Pay Retreat," Business Week, December 28, 2006; "Investors Oppose SEC’s Exec-Pay Disclosure Change,” Dow Jones Newswire, January 31, 2007; Interview with David Smith, April 2008, Washington, DC; “CEO Politics,” Wall Street Journal, January 9, 2007; "President Bush Delivers State of the Economy Report,” January 31, 2007, https://georgew bush-whitehouse.archives.gov/news/releases/2007/01/20070131-1.html. 
investors sought the right for shareholders to vote on executive pay packages. It would be a long, uphill struggle to obtain it. ${ }^{33}$

Controversy over executive compensation was not limited to the United States. The United Kingdom in 2002 adopted a law requiring advisory shareholder votes on directors' remuneration reports, which originated in the U.K.'s governance cookbooks of the mid-1990s-such as the Greenbury Report and the Hampel Report- that advocated the practice. When Tony Blair's New Labour government took power in 1997, it advanced say on pay as a way of addressing inequality without involving government. Almost immediately, there was a donnybrook at the pharmaceutical company GlaxoSmithKline, when 61 percent of shareholders voted "no," a shock felt throughout the business and investing worlds. Among Glaxo's shareholders was CalPERS. A month after the vote, Phil Angelides, California's state treasurer and a CalPERS trustee, joined the chief investment officers of six other state plans to press the SEC to adopt a UK-style law. ${ }^{34}$

Union pension plans introduced their first say-on-pay proposals during the 2006 season. Leading the shareholder side was AFSCME's pension fund, the driving force behind which was the late Richard Ferlauto. He'd worked for ISS's Taft-Hartley division until 1997, then went to the AFL-CIO’s Office of Investment, and was hired four years later by Gerald McEntee, AFSCME's president. Among AFSCME's first targets were Countrywide Financial and Home Depot. Countrywide

33 “New SEC Rules Make Pay More Transparent," Washington Post, July 16, 2007; "How Much Does Your CEO Really Make? Go Figure," Washington Post, February 8, 2009; Silvers in "Disclosure Rule to Ease Executive Pay Comparisons," P\&I, September 4, 2006. Most companies pay their executives a mixture of salaries, perks, bonuses, stock options and other equity awards that might be paid out in one year or spread out over time. The Walt Disney Company's report to the SEC showed CEO Robert Iger receiving \$30.6 million in 2008. One of the compensation consultants contacted by the Washington Post was Graef Crystal. To the SEC figure he added the shares that actually vested or were exercised; option awards from the grants of the plan-based awards table that showed what Iger got in free stock and option shares for the year; awards granted in 2008 that would have future payouts, including future estimated payment for restricted stock units; and options granted to Iger to enter into an extended employment agreement that were scheduled to vest through 2013. Graef's calculations showed Iger's 2008 compensation to be worth $\$ 51.1$ million. Crystal said that counting awards granted in 2008 but not to be realized until future years was like saying, "Part of the bonus is 100 pounds of coffee. Someone says we don't count that because she didn't drink it. But it's still sitting on your shelf."

34 "The Day Investors Said Enough Is Enough," The Guardian, May 20, 2003; "Vodafone Board Faces TUC Opposition over Pay Awards," Dow Jones Newswires, July 20, 2002; "Calif., Other States Urge More Corporate Reforms," Reuters, June 30, 2003; interview with Janet Williamson, TUC, November 2008, London; "Executive Pay Is at Issue," Wall Street Journal: Europe, July 11, 2002; Randall S. Thomas and Christoph Van der Elst, "Say on Pay around the World," Washington University Law Review 92 (2015): 653-731. 
was an interesting choice, the nation's third-largest lender of subprime mortgages. Delinquencies on those mortgages were rising in 2006, a canary in the coal mine. Its CEO and board chairman, Angelo Mozilo, was one of the highest paid executives in the nation. That year he racked up total compensation of \$41 million, realized an additional $\$ 199$ million from exercised options, and held other exercisable options worth \$204 million. These mind-numbing figures were sure to hit the outrage constraint. Said a compensation consultant, "If you are going to pick on anybody, he would be a good guy to focus on.” In response to a say-on-pay proposal, Countrywide's board said that having shareholders vote on pay would hamper efforts to recruit and retain excellent senior executives. Ferlauto asked whether the board had to give Mozilo that much equity "to keep him happy and attached to the company? As a company founder, is he going anyplace?” The following year, Countrywide reported losses totaling $\$ 3.9$ billion.

At Home Depot, shareholders were unhappy that the company's stock price had fallen 9 percent since 2000, when CEO Robert Nardelli had been hired, as against a 185 percent increase at rival Lowe's Companies. Yet Nardelli took home nearly \$125 million in pay, more than his Lowe's counterpart. AFSCME, joined by CalPERS and the CtW Investment Group, urged shareholders in 2006 to withhold votes from ten of the company's eleven directors. (The eleventh director was new to the board, and his name was Angelo Mozilo.) Demonstrators stood outside the meeting, one of them wearing a chicken costume and an orange Home Depot apron. The demonstrators chanted, "Hey Nardelli! Your stock price turned to jelly!" Inside the meeting, Nardelli refused to respond to questions about his compensation and enforced strict time limits on comments from the floor. AFSCME's proposal received 38 percent of votes cast. The vote surely would have been higher had Home Depot disclosed that, on five occasions, its board had approved backdated stock options, news the company sat on until a month after the meeting. After Home Depot's backdating revelation, Richard Trumka sent an open letter to Bonnie Hill, a Home Depot director, demanding he board fire lead director Ken Langone and recoup all gains from backdated options. Hill agreed to meet with Trumka, promising "a hard look” at Nardelli's pay package. Trumka's letter came several weeks after Bill Patterson had sent a letter of his own to Hill. ${ }^{35}$

35 "With Links to Board, Chief Saw His Pay Soar," New York Times, May 24, 2006; "Home Depot CEO Nailed over Pay," Associated Press, May 26, 2006; consultant quoted in Todd Davenport, "Countrywide Shareholders to Vote on Exec-Pay Proposal," American Banker, June 14, 2006; “Behind Nardelli’s Abrupt Exit," Wall Street Journal, January 4, 2007; "Groups Blast Home Depot over Stock Option Mistake," Associated Press, June 29, 2006; "Home Depot Annual Meeting Ground Zero in Pay Debate,” Wall Street Journal, May 24, 2006; “AFL-CIO: Meeting 
The business community said that investors didn't deserve a say on pay because they were not as well informed as directors, a clear argument for placing directorial discretion above shareholder views. The claim is a thin reed; boards can easily supply investors with information about the rationale for their pay recommendations, as was happening in the United Kingdom. In ordinary times, institutional investors tend to support management in voting on executive pay proposals. But the 2000s were not ordinary times; repeated scandals had shaken investor confidence in the executive pay-setting process. What management feared is what happened in 2011, after Dodd-Frank mandated say-on-pay voting: Glass, Lewis, a prominent proxy advisor, recommended against management in 22 percent of say on pay votes; ISS recommended against in 11 percent of the votes. No executive wanted to be part of the one in five or one in ten whose pay package would be opposed by shareholders. In fact these fears were overblown, as we will see. ${ }^{36}$

with Home Depot Dir. Hill Productive," Dow Jones News Service, September 7, 2006; "Home Depot Defends CEO Pay but Reviewing Policies,” Dow Jones News Service, September 18, 2006; interview with Dan Pedrotty, March 2007, Washington, DC.

36 Fabrizio Ferri and James Weber, "AFSCME vs. Mozilo ... and "Say on Pay" for All! (A)," Harvard Business School, case study 9-109-009, March 18, 2009; statement of Thomas J. Lehner, "Written Testimony and Comments for the Record," House Financial Services Committee, May 25, 2006; Damon A. Silvers and Michael I. Garland, "The Origins and Goals of the Fight for Proxy Access” (2004) at https://www.sec.gov/spotlight/dir-nominations/silversgarland022004. pdf; Yonca, Ertimur, Fabrizio Ferri, and David Oesch, "Shareholder Votes and Proxy Advisors: Evidence from Say on Pay,” Journal of Accounting Research 51 (2013): 951-96. ISS is the largest proxy advisors in the United States, with Glass, Lewis a distant second. Precisely how many proxy votes are swayed by ISS is a matter of dispute. But there's no doubt that the figure is substantial - somewhere between 6 to 13 percent at the low end and 40 percent at the high end. In some major battles, such as Hewlett Packard's acquisition of Compaq and the vote against CEO Michael Eisner at Disney, ISS is credited with tipping the balance. More striking is the finding that no proxy proposal was ever successful unless ISS had given its imprimatur. Although ISS has plenty of pension plans as clients, the people who pay its bills are the mutual funds. As much as ISS wants to be a thought leader on corporate governance, it has to be responsive to the inclinations of its customers. U.S. General Accounting Office (GAO), Corporate Shareholder Meetings: Issues Relating to Firms That Advise Institutional Investors on Proxy Voting (Washington, DC, June 2007), 13; Stephen Choi and Jill Fisch, "On Beyond CalPERS: Survey Evidence on the Developing Role of Public Pension Funds in Corporate Governance," Vanderbilt Law Review 61 (2008): 315-54; Paul Rose, “The Corporate Governance Industry,” Journal of Corporation Law 32 (2007): 887, 889; Stephen Choi, Jill Fisch and Marcel Kahan, "The Power of Proxy Advisors: Myth or Reality?” Emory Law Journal 59 (2010): 869; Jacqueline Garner, and Ralph A. Wakling, "Electing Directors," Journal of Finance 64 ( 2009): 2389-2421; Peter Iliev and Michelle Lowry, "Are Mutual Funds Active Voters?” The Review of Financial Studies 28, no. 2 (2014): 446-85. 


\section{Take it to Congress}

Barney Frank was a liberal Congressional representative with close ties to the labor movement. Despite declining membership in the private sector, labor unions in the United States retained political influence within the Democratic Party as a result of their ability to mobilize voters and make financial contributions during elections.

In November 2005, Barney Frank introduced "The Protection against Executive Compensation Abuse Act," intended to address "runaway pay" and "pay disparities" between executives and ordinary workers. Its centerpiece was say on pay. Other provisions included mandatory clawbacks at companies forced to restate their earnings, a more stringent version than SarbanesOxley's. No doubt with Jack Welch in mind, the bill required companies to disclose the details of executive compensation packages, including perks such as free apartments, low-cost loans, and company-paid income taxes. ${ }^{37}$

Frank held hearings in 2006 in front of the House Financial Services Committee. The AFL-CIO's Brandon Rees testified in favor of the bill, but there was powerful opposition. The Business Roundtable drubbed say on pay as "unwise and ultimately unworkable" and warned that it would lead to classaction lawsuits against executives. Hedge funds were very much on the Roundtable's mind as a source of those lawsuits and union investors too. Regarding say on pay, the Roundtable warned, "If we adopted a system where small groups of activist shareholders used the process to politicize corporate decision-making, the consequences could very well be destabilizing." Frank's bill died, but it burnished his reputation as an expert in financial regulation, even taking him to Davos. ${ }^{38}$

37 "Frank's Bill Seeks Greater Disclosure of Executive Pay," Boston Globe, November 11, 2005; "Frank Introduces Legislation to Protect Shareholders from Abuse of Executive Compensation," US Federal News Service, November 10, 2005; "Even with Disclosure, Investors Have Little Say on Pay," Dow Jones Newswires, January 31, 2006; letter from William Samuel, director, AFL- CIO Department of Legislation to Senators Chris Dodd and Richard Shelby, April 24, 2007, courtesy of Dan Pedrotty.

38 "Frank's Bill Seeks Greater Disclosure"; Siobhan Hughes and John Godfrey, "House Democrat Targets Executive Pay," Wall Street Journal, November 10, 2005; "New SEC Rules to Lift the Veil on CEO Pay," Kiplinger, December 9, 2005; "AFSCME Urges US Companies to Curb Executive Pay," Reuters, December 7, 2005; "Labor of Love," Institutional Investor, March 14 2005; "Union Funds Champs of Proxy Season,” P\&I, February 5, 2007; Ferri and Weber, "AFSCME vs. Mozilo"; "U.S. House Lawmakers Clash on Issue of CEO Pay," Dow Jones Newswires, May 26, 2006; statement of Thomas J. Lehner, "Written Testimony and Comments for the Record." 
After he became chair of the House Financial Services Committee in January 2007, Frank met with the media at the National Press Club, where he announced that, over the next two years, his committee would hold hearings about the causes and consequences of inequality and weak wage growth. Hammering home that a "small segment" of executives had benefited from economic growth while the majority of Americans had not, he kept his say-on-pay bill alive. According to David Smith, Frank's advisor, the focus on say on pay was a reflection of "a new Chairman searching around for attention and getting stuff that was on the shelf and ready to go." Say on pay was easy to explain to constituents concerned about inequality. Smith said that Frank thought say on pay would appeal to some of the working-class voters who'd put Bush in office in $2004 .^{39}$

Democratic leaders believed in 2007 that they could not overhaul immigration law or expand free trade unless they responded to what Robin Toner dubbed "the new populism." To keep the votes of the middle class, anxious about flat wages and downward mobility, in the upcoming elections, the Democrats would have to tilt left. Say on pay was one of their responses. But as Toner reported, "Many on the left worry that the Democratic establishment is merely paying lip service.” Say on pay was a good political issue: Who wouldn't like the idea of "voting" on the boss's pay? As a remedy for inequality, however, it was wanting.

Republicans recognized that they too were vulnerable to the new populism. President George W. Bush gave a speech addressing inequality at Wall Street's Federal Hall after making a surprise visit to the New York Stock Exchange in January 2007. He acknowledged that "a few extravagant pay packages" had "disgusted" millions of Americans. Said Bush, "The fact is that income inequality is real. It has been rising for more than twenty-five years," this contrary to what some conservatives had claimed. The audience of bankers and brokers reacted with silence but cheered when Bush said he would cut taxes. ${ }^{40}$

Companies also were having a difficult time persuading the public that executives deserved their pay. Damaging to their cause were two astronomical

39 Damian Paletta, "US Rep Frank Calls on Businesses for Wages, Trade Deal," Dow Jones Newswires, January 3, 2007; "Behind Nardelli's Exit”; Smith interview. On Countrywide and its role in the financial crisis, see Charles Ferguson, Inside Job: The Financiers Who Pulled Off the Heist of the Century (London: Oneworld, 2014) and Neil Fligstein and Alexander F. Roehrkasse. "The Causes of Fraud in the Financial Crisis of 2007 to 2009: Evidence from the Mortgagebacked Securities Industry,” American Sociological Review 81, no. 4 (2016): 617-643.

40 Robin Toner, “A New Populism Spurs Democrats on the Economy,” New York Times, July 16, 2007; "President Bush Delivers State of the Economy Report”; “Bush Takes Aim at Companies' Lavish Executive Pay,” Associated Press, January 31, 2007. 
severance payments-at Pfizer and at Home Depot-that came to light early in 2007. At Pfizer, the board awarded CEO Hank McKinnell severance pay worth nearly \$200 million, even though the company's share price had fallen 43 percent during his five-year tenure. McKinnell retired from Pfizer more than a year earlier than intended. Ironically, Pfizer was a member of CII and ostensibly a company with exemplary corporate governance. ${ }^{41}$

Home Depot was back in the news in 2007 over its gift to CEO Robert Nardelli: an exit package worth a head-turning \$210 million. Shareholders surely were happy when Home Depot's shares rose on news of Nardelli's departure. But it was hubris on the board's part to give Nardelli so much money following the shareholder protests back in May. Barney Frank released a scorching statement about Nardelli's exit package: "Some defenders of CEO pay argue that CEOs are rewarded for increasing the stock or the overall value of the company, but judging by today's market reaction, Mr Nardelli's contribution to raising Home Depot's stock value consists of quitting and receiving hundreds of millions of dollars to do so.” Breaking ranks with the business community, Charles T. Munger, business partner of Warren Buffett, predicted that say on pay "might dampen some of the excess." Chartered financial analysts (CFA) also were heretical. A survey of CFAs by the Center for Financial Market Integrity found that three-fourths were in favor of say on pay. On the other hand, William Donaldson, in a report published by the Committee on Economic Development, an organization of corporate liberals, publicly opposed say on pay along with two other former SEC commissioners. ${ }^{42}$

Frank reconvened say-on-pay hearings in March 2007. Although Bush said that he would not sign a bill containing say on pay and most Republicans were opposed, with Democrats in control of Congress and inequality still a very hot issue, the bill stood a decent chance of passage. Frank met with representatives from 130 pension funds at an event organized by CII and warned that, if say on pay passed and directors were to "simply shrug off the votes, then there could be more drastic reform," an allusion, perhaps, to proxy access. Even with three former SEC chairs, but not reformer Arthur Levitt, coming out publicly against Frank's bill, the congressman had the power to push the issue through the House. Democrats had the votes, and Frank's bill passed by 269-134 in April. ${ }^{43}$

41 “Give It Back, Hank,” Washington Post, December 21, 2006. Regarding conservative views on inequality, see Paul Krugman, Peddling Prosperity: Economic Sense and Nonsense in the Age of Diminished Expectations (New York: W.W. Norton, 1994), chap. 5.

42 "Everyone from Pres. Bush to Union Activists Asks: How Can CEO Pay Be Brought Down to Earth?” Associated Press Newswires

43 “U.S. Rep. Frank: Say-on-Pay Would Test Directors,” Reuters, March 19, 2007; “AFL-CIO’s PayWatch Website Exposes Rigged CEO Pay System,” PR Newswire, April 5, 2007. 
By that time, candidates were on the hustings for the upcoming presidential campaign. One of those prospective presidents was Illinois Senator Barack Obama, who said say on pay would give shareholders "the power to debate and fight back against exorbitant executive compensation." Certainly, say on pay was a way of saying to voters, "We hear your pain." Several hours after the House passed Frank's bill, Barack Obama introduced a companion bill in the Senate. President Bush once again warned that he would not sign a say-onpay bill. ${ }^{44}$

Activists pushed for say on pay in parallel with Congress. AFSCME and Walden Asset Management, a social investor, created a coalition around the issue including several large public funds-from California, Connecticut, Boston and New York City-as well as the AFL-CIO, Hermes Investment, Calvert Investments, Amalgamated Bank, and several religious pension funds belonging to the Interfaith Center on Corporate Responsibility. The group submitted forty-four say-on-pay proposals in 2007, more than half the season's total. ${ }^{45}$

With the SEC, Congress, hedge funds, and institutional shareholders all nipping at their heels, companies were more willing to compromise than in previous years, not only on executive compensation but on other issues. Because of this, investors in 2007 withdrew 45 percent of their proposals related to corporate governance. The intensity of consultation between companies and investors was unprecedented. The head of CII, Patrick McGurn, said "We've never had a season that had so much activity going on in the wings and much less taking place center stage."46

Several companies reached out to the AFSCME-Walden group in search of a compromise. Led by the besmirched Pfizer, they called themselves the "Working Group on the Advisory Vote on Executive Compensation Disclosure.” Included in the invitation-only group that met at Pfizer's headquarters in New York were

44 "House Votes to Have Shareholders Weigh in on Exec Pay," Los Angeles Times, April 21, 2007; Jie Cai and Ralph A. Walkling, “Shareholders' Say on Pay: Does It Create Value?” Journal of Financial and Quantitative Analysis 46, no. 2 (2011): 299-339.

45 Ertimur, Ferri, and Muslu, "Shareholder Activism and CEO Pay"; Riskmetrics, 2007 Postseason Report; “CEO Compensation Survey,” Wall Street Journal, April 9, 2007.

46 Rob Bauer, Frank Moers, and Michael Viehs, "The Determinants of Withdrawn Shareholder Proposals," SSRN working paper, 2012; “Shareholders Push for Vote on Executive Pay,” Wall Street Journal, February 26, 2007; Edward Iwata, "Backdated Options May Snare Some Directors as Critics Blast Rubber-Stamping," USA Today, March 29, 2007; Riskmetrics, 2007 Postseason Report; Jie Cai, Jacqueline L. Garner, and Ralph A. Walkling, "Electing Directors," Journal of Finance 64, no. 5 (2009): 2389-2421; “New Breed of Directors Reaches Out to Shareholders," Wall Street Journal, July 21, 2008. 
twelve companies, weighted toward pharmaceuticals (Bristol-Myers, ColgatePalmolive, and Schering- Plough) and finance (AIG, JP Morgan Chase, Prudential). The group had detractors in the business world, people who were wary of anything that might encourage say on pay. Martin Lipton distributed a letter calling the Working Group's ideas “corporate governance run amuck” and proffered the usual criticism that directors should not be replaced by shareholders when it came to setting executive pay. ${ }^{47}$

A third group was dead set against say on pay. Co-led by the Carpenters and the U.S. Chamber of Commerce, its other members included Citigroup and DuPont. Ed Durkin, often the renegade, had developed two alternatives to say on pay. His commonsense pay plan included a cap of \$1 million on a CEO's salary and payment in restricted shares instead of stock options, but this plan rarely received more than 10 percent of votes cast, its Clinton-like cap being the kiss of death. Durkin later formulated the pay-for-superior-performance plan, which called for benchmarking a company's financial performance-and CEO compensation-to the performance of its peers. This second plan fared better than the commonsense approach, averaging 30 percent of votes cast during the 2006 and 2007 seasons, but never came close to the popularity of proposals for say on pay. ${ }^{48}$

Durkin believed that activism should be based on "thoughtful investigative work on compensation plans" that would require a company to take specific actions, such as benchmarking, whereas say on pay simply communicated dissatisfaction and did so in a disengaged way. The building trades always had been more cooperative with employers than most other private-sector unions. Part of the reason was that construction workers obtained support for their apprenticeship programs from the industry's unionized contractors. More than a few construction workers left the trades and obtained a contractor's license. They then became employers, and others aspired to be like them. The unions had a voluntarist legacy that not infrequently favored private orderings over political solutions. ${ }^{49}$

Sixty-one proposals made it to a vote during the 2008 season; the AFSCMEWalden coalition filed more than half of them. Companies fought back by sending letters and making phone calls to their largest investors. Although the

47 "Institutional Investors to Press Companies," Global Proxy Watch, February 9, 2007; ISS, "Director Elections."

48 AFL-CIO Executive Council, "Model Guidelines for Delegated Proxy Voting Responsibility," February 1991; Richard Marens, "Going to War with the Army You Have: Labor's Shareholder Activism in an Era of Financial Hegemony,” Business and Society 47 (2008): 312-42; Ertimur, Ferri, and Muslu, "Shareholder Activism and CEO Pay,” 543, 581; Kara Scannell, "Policy Makers Work to Give Shareholders More Boardroom Clout,” Wall Street Journal, March 26, 2009.

49 “Firms, Investors Trying More Talk, Less Acrimony,” Wall Street Journal, July 16, 2007. 
proposals received an average vote of 42 percent, about the same as in 2007, now there were eleven majority votes in favor. ${ }^{50}$

That spring, Senator Barack Obama again urged passage of his say on pay bill. His opponent, Senator Hillary Clinton (D-NY), sought support for her bill. On the Republican side, candidate and Senator John McCain said he backed say on pay as a concept, although he never endorsed any legislation. Obama's bill died in the Senate, but it wasn't Republicans who killed it. Rather, it was Senator Christopher Dodd (D-NH), now chairman of the Senate Banking Committee, who refused to hold a hearing on the bill. Dodd too had thrown his hat into the presidential ring in January and had no desire to help either of his opponents. ${ }^{51}$

\section{Say on pay and Dodd-Frank}

The global banking system collapsed in September 2008. The initial response from the Bush administration came a month later in the form of the Emergency Economic Stabilization Act, most famous for its Troubled Asset Relief Program (TARP), which authorized the Treasury to spend up to $\$ 700$ billion on the purchase of depreciated assets. The quid pro quo was that the government asserted the right to more closely manage the financial institutions receiving loans. Twelve million people now had underwater mortgages, Seven million lost their homes, and employment fell by nearly 9 million. People were outraged, and, as in 1893 and 1932, they blamed the bankers for their losses. Although the economic details were unknown to most people, there was a feeling that bankers had made out like bandits during the runup to the crisis and, in fact, they were right. By 2005, executives in the financial sector earned 250 percent more than comparable executives, and the size distribution of firms could explain only one-fifth of the premium. Stoking public anger were reports that rescued banks continued to spend lavishly. Merrill renovated its corporate offices, and Citibank

50 Randall S. Thomas, Alan R. Parmiter, and James F. Cotter, "Dodd-Frank's Say on Pay: Will It Lead to a Greater Role for Shareholders in Corporate Governance?” Cornell Law Review 97 (2012): 1213-66; “Investors Push 90 Companies for Say on CEO Pay," Reuters, January 24, 2008; "Say on Pay Movement Loses Steam," Washington Post, May 6, 2008; "Push for Say on Pay Is Losing Its Oomph," Crain's New York Business, June 23, 2008; “A Brighter Spotlight, Yet the Pay Rises,” New York Times, April 6, 2008.

51 “Obama Pushes Say on Pay," CFO.com, April 11, 2008; "Say on Pay Bills More Cudgel than Reality,” Associated Press, June 15, 2008; "Presidential Rivals Differ on Senate 'Say on Pay' Bill,” Best’s Insurance News, June 4, 2007. 
placed orders for corporate jets. The anger led to national protests and to the Occupy Wall Street movement.

This crisis and the related scandals reignited demands for say on pay. During the fall of 2008, investors prepared over one hundred say-on-pay proposals, of which two-thirds reached a vote. Union plans divided their proposals among companies implicated by the financial crisis (like Bank of America), those where labor had no side interests (for example, Apple and Lexmark), and those where it had potential collateral interests (like CenturyTel, Walmart, and Windstream). In November, AFSCME's Ferlauto said that the time had come for a legislative package combining say on pay and proxy access, a one-two punch for shareholders. ${ }^{52}$

TARP included restrictions on bankers' compensation, some of them drawn from the governance recipes of the previous seven years. No bonuses could be paid at institutions receiving TARP funds unless they were in the form of restricted stock and did not fully vest during the TARP period. Clawbacks would occur if there were "materially inaccurate" restatements based on unlawful reporting. Recipients were told to eliminate incentive pay that encouraged "unnecessary and excessive" risk-taking. TARP also imposed a cap of $\$ 500,000$ on the tax- deductible compensation of senior executives.

On January 6, 2009, two weeks before his presidential inauguration, President Obama proposed the American Recovery and Reinvestment Act (ARRA). Much of the bill detailed how money would be spent on infrastructure and aid to states. Title VII spelled out "limits on executive compensation" for banks receiving TARP funds. While it carried over TARP's provisions, now say on pay was required at TARP recipients. To satisfy the citizenry, ARRA limited luxury spending by executives of TARP companies. The president signed the bill on February 17. After pay voting commenced, only a handful of TARP recipients received "reject" votes greater than 30 percent. At Goldman Sachs, 98 percent of votes ratified the board's compensation recommendations. ${ }^{53}$

52 Baird Webel and Marc Lebonte, Troubled Asset Relief Program (TARP): Implementation and Status, report by the Congressional Research Service, June 27, 2013; "Wall Street's Bone-Headed Bonuses," Los Angeles Times, January 31, 2009; "Shareholders See Victory in Obama Administration," Pensions and Investments, November 10, 2008. On compensation in finance, see Thomas Phillopon and Ariell Reshef, "Wages and Human Capital in the US Finance Industry: 1909-2006,” Quarterly Journal of Economics 127 (2012): 1551-1609.

53 Social Investment Forum, "Socially Responsible Investors, Labor, Pension Funds Agree: Bail-Out Recipients Facing Say on Pay Resolutions Should Adopt Policy,” February 24, 2009; "Wall St Pay Moves in Cycles. (Guess Where We Are Now)," New York Times, February 5, 2009; "U.S. Targets Excessive Pay for Top Executives," Washington Post, June 11, 2009; "Investors Say Yes on Pay at TARP Firms," Wall Street Journal, September 2, 2009; "Shareholders Challenge 
It remained uncertain whether Congress would extend say on pay to the thousands of companies not receiving aid. In May, Senators Charles Schumer (DNY) and Maria Cantwell (D-WA) introduced a bill for mandatory say on pay, which found its way into Dodd's financial overhaul. To send a message to companies and to Congress, shareholders flooded the system with say-on-pay proposals during the 2009 and 2010 seasons. By the time Congress voted on Dodd-Frank, dozens of companies voluntarily had adopted the measure. On July 21, 2010, President Obama signed the Dodd-Frank Wall Street Reform and Consumer Protection Act. Say on pay would go into effect at all companies in 2011, one of Dodd-Frank's first provisions to be implemented. ${ }^{54}$

Business's dire warnings about say on pay never came to pass. As in the United Kingdom, investors rarely piled on against management. At Russell 3000 companies in the United States, 91 percent of shareholders on average voted in favor of proposed pay packages. An article in the Cornell Law Review indicated this "showed strong support for existing pay practices." And average support has changed little since then. There is, however, a different way of analyzing the data. From 2011 to 2016, there were 870 companies that had at least one pay vote below 70 percent-considered a threshold-and 210 with at least one vote below 50 percent. Small companies-those in the Small Cap 600-were twice as likely as large ones-the S\&P 500-to receive less than majority votes.

Then there is the matter of insider and absentee votes. Insider holdings vary, but estimates put them at around 21 percent of common shares in the average company. Take Viacom, an illustrative example, albeit one of the most egregious. In 2011, only 3.4 percent of shares were voted against the board's compensation plan, seemingly a resounding show of support for management. But the company was closely held by its CEO, Sumner Redstone, his family, and other company executives. If ones takes their shares out of the picture, twothirds of independent shareholders cast their ballots against management. ${ }^{55}$

Goldman Sachs as It Prepares to Pay Record Bonuses,” Investment Weekly News, October 21, 2009.

54 Interview with Damon Silvers, January 2009, Chicago; ACGR 2009; "Shareholders to Focus on Executive Compensation," Wall Street Journal, January 12, 2009; "Senator Schumer and the SEC Separately Propose Action on Corporate Governance Matters," Mondaq, May 22, 2009; "In Victory for Obama, House Panel Approves Restraints on Executive Pay," New York Times, July 29, 2009.

55 Thomas, Parmiter, and Cotter, "Dodd-Frank's Say on Pay," 1248; James F. Cotter, Alan R. Palmiter, and Randall S. Thomas, "The First Year of Say-on-Pay under Dodd-Frank: An Empirical Analysis and Look Forward,” The George Washington Law Review 91 (2013): 9671011; Semler Brossy, 2016 Say on Pay Results 
During the first six months of 2011, ISS had recommended voting against the board's compensation recommendations at one out of every ten companies. Some of the reasons it advised "no" votes were defects with performance-based pay and lack of transparency. The HR Policy Association, a lobbying group comprising 325 large companies, launched a new organization, the Center on Executive Compensation, to fight say on pay. It turned the conflict of interest issue back on ISS by alleging that ISS's consulting business was influencing its proxy recommendations. The center urged all companies to "scrutinize proxy advisory firms for bias and errors" and asked the SEC to force ISS to disclose its client relationships. ${ }^{56}$

Did say on pay change anything? In fact, it did. Evidence from the United States and the United Kingdom indicates the issue led to closer engagement between investors and companies. To avoid the embarrassment of a large number of "against" votes, companies actively tried to win shareholders over before the annual meeting by engaging the largest institutional shareholders. Any unenthusiastic votes were followed up by additional meetings. More than half of these meetings were not made public; most involved face-to-face discussions. There also were communications directed to employee-shareholders, people with stock in the company's 401(k) plan. "That's one of the reasons I like this say-on-pay idea," said the AFL-CIO's Dan Pedrotty. "It's an inexpensive way not only for investors but also employees to exhibit their displeasure. Short of employees going on the board, I think something like say on pay is a good way to go." 57

Assessing the effects of say on pay is not easy. Some studies find that it raised the sensitivity of CEO pay to share-price performance; others find no evidence that excess compensation (unrelated to performance) decreased following a say-on-pay vote, no matter how negative. There is no evidence, however, that negative votes led to lower levels of CEO pay. In other words, say on pay

56 “Companies Fight Back on Executive Pay," Wall Street Journal, February 7, 2011; "Business Fights Back against ISS and on Say on Pay,” Crain's New York Business, June 27, 2011. The key determinant of say-on-pay outcomes were the judgments of proxy advisors. A negative recommendation from ISS could push support down by 28 percent. Ertimur, Ferri, and Oesch, "Shareholder Votes and Proxy Advisors"; Semler Brossy, 2016 Say on Pay Results; Marc Goldstein, "The State of Engagement between U.S. Corporations and Shareholders," IRRC Institute, February 22, 2011.

57 Goldstein, "The State of Engagement between U.S. Corporations and Shareholders"; "Executive Pay Vote Spurs Shifts in Policies"; "Say on Pay Voting Eases Opposition to Board Nominees"; Pedrotty interview. 
may have tightened the pay-performance relationship. What it did not change was the upward march of executive pay. ${ }^{58}$

Richard Trumka had been optimistic that say on pay would give shareholders "new tools to fight back" against out-of-control CEO pay." But, in the end, say on pay proved a Pyrrhic victory. After pay voting commenced in 2011, few shareholders voted against CEOs, who continued to rack up stratospheric earnings. The ratio between CEO pay and that of employees steadily widened, from 227 in 2010 to 339 in 2018. The New York Times financial reporter Jesse Eisinger judged say on pay an example of "toothless public regulations."59

\section{Pay ratios}

Several months before Dodd-Frank became law, New Jersey's Democratic Senator Bob Menendez inserted a provision into the bill requiring companies to disclose in their annual report the ratio of the CEO's compensation to that of the median employee. Menendez quoted Louis Brandeis's sunlight quip, asserting that disclosure would encourage fair pay. "The middle class pay has stagnated while CEO pay has skyrocketed," he said. Dodd-Frank had kicked the payratio provision over to the SEC for implementation. Over the next five years, the

58 Ricardo Correa and Ugur Lel, "Say on Pay Laws, Executive Compensation, CEO Pay Slice, and Firm Value around the World," FBR International Finance Discussion Paper no. 1084 (2013); Steven Balsamet, Jeff Boone, Harrison Liu, and Jennifer Yin, "The Impact of Say-on-Pay on Executive Compensation,” Journal of Accounting and Public Policy 35, no. 2 (2016): 162-91; Ferri and Maber, "Say on Pay Votes"; Vicente Cufiat, Mireia Gine, and Maria Guadalupe, "Say Pays! Shareholder Voice and Firm Performance,” Review of Finance 20 (2016): 1799-1834; Walid Alissa, "Boards' Response to Shareholders' Dissatisfaction: The case of Shareholders' Say on Pay in the UK," European Accounting Review 24 (2015): 727-52; Martin J. Conyon, "Executive Compensation and Board Governance in US Firms," Economic Journal 124 (2013): F60-F89. But see Kelly Brunarski, T. Colin Campbell, and Yvette Harman, "Evidence on Outcome of Say-onPay Votes: How Managers, Directors and Shareholders Respond," Journal of Corporate Finances 30 (2015): 132-49; Peter Iliev and Svetla Vitanova, "The Effect of Say on Pay Vote in the U.S.," working paper, Pennsylvania State University, February 2015; Christopher S. Armstrong, Ian D. Gow, and David F. Larcker. "The Efficacy of Shareholder Voting: Evidence from Equity Compensation Plans," Journal of Accounting Research 51, no. 5 (2013): 909-50.

59 "Labor Puts Executive Pay in the Spotlight," New York Times, April 9, 2011; Mishel and Schieder, "Stock Market Winds"; Mishel and Davis, "Top CEOs Make 300 Times More"; "For the Wealthiest, a Private Tax System That Saves Them Billions,” New York Times, December 29, 2015; Jesse Eisinger, "In Shareholder Say-on-Pay Votes, More Whispers Than Shouts," New York Times, June 26, 2013; Gretchen Morgenson, "Shareholders' Votes Have Done Little to Curb Lavish Executive Pay,” New York Times, May 16, 2015. 
business community fought activist shareholders, mostly union investors, to prevent the SEC from putting the rule into practice. ${ }^{60}$

Among the first to discuss pay ratios was management guru Peter Drucker in his essay "Overpaid Executives: The Greed Effect," published in the mid-1980s when executive compensation was starting to climb above the flat line of its postwar years. He noted that high CEO salaries bred resentments that "disrupt the team" and made adversaries of executives and ordinary employees. Like others at the time, Drucker pointed to the Japanese, "our toughest competitors," where pay gaps between top and bottom were much smaller than in the United States. "Yet their companies aren't doing too badly," said Drucker. Drucker proposed that companies voluntarily adopt a preset multiple of CEO pay over lower-level employees in the range of 15-20:1. In 1978, the ratio stood at 30:1. ${ }^{61}$

The person who brought the issue to Congress was Martin Olav Sabo, a liberal Democrat from Minnesota. In 1991, Sabo proposed the Income Equity Act, which would eliminate corporate tax deductions for executive pay in excess of twenty-five times that of the lowest-paid full-time worker. Relentless, he reintroduced the bill over the years, the last time in 2005 right before his retirement. He harbored no illusion that the bill would pass but viewed it as a touchstone for debate and a way to draw national attention to inequality. Knowing the ratio, he said, "could "prompt business leaders to take a closer look at how they may be contributing to America's widening economic divide."62

Others picked up on Sabo's idea. United for a Fair Economy (UFE), a Bostonbased advocacy organization with ties to social investors and the labor movement, started a campaign in 1997 called Close the Wage Gap. UFE identified CEOs whose compensation leapt up after layoffs and plant closures. Its leading “job- shifter” was General Electric's Jack Welch, whose high pay, it said, was a reward for shipping jobs to Mexico. Together with a social investor -Franklin Research and Development (later Trillium)-UFE submitted resolutions at GE in

60 “Executive Pay Law 'Nightmare' on Wall Street," Financial Times, August 30, 2010.

61 Peter F. Drucker, Frontiers of Management (1986; New York: Routledge, 2011), 138-43; Drucker, "Reform Executive Pay or Congress Will," Wall Street Journal, April 24, 1984; Lawrence Mishel and Jessica Schieder, "Stock Market Headwinds Meant Less Generous Year for Some CEOs,” Economic Policy Institute, July 12, 2016.

62 "What's Your Boss Worth? 35 Times Your Salary? 1,000 Times? The Workforce Gets Angry," Washington Post, August 5, 1990; Robert Borosage, "Buchanan's Challenge: Is Anyone Listening? The Nation, March 18, 1996; "Sabo Fights Lonely Fight of Old-Fashioned Liberal," Minneapolis Star-Tribune, February 10, 1997; Sabo quote in Martin Sabo, "No One Should Be Left Behind in Our Nation's New Economy,” Tax Foundation's Tax Features, October 1, 1999; “Rep. Sabo Introduces Income Equity Act of 2005,” US Federal News, July 12, 2005. 
1998 and 1999, asking the company to set a cap on executive pay similar to what Sabo was proposing. The resolutions each received a bit below 6 percent. ${ }^{63}$

Social investors filed multiple pay-ratio resolutions, such as a Walmart proposal submitted by ICCR on behalf of the Sisters of the Holy Names of Jesus and Mary and other faith-based investors. It noted that the company's CEO received one thousand times the average pay of its "associates," who contributed to the company's success and should be rewarded for that role. There's evidence that investors use pay ratios as a signal that executives are acting against their interests. When ratios are high, they are associated with more negative say-on-pay voting results. The AFL-CIO, however, was lukewarm to Sabo's approach. Like other union investors, it never filed shareholder proposals on the topic and played no apparent role in the Menendez proposal. ${ }^{64}$

Barney Frank and Chris Dodd were skeptical of the Menendez approach. But Menendez sat on the Senate Banking Committee, and Dodd needed his vote. It's easy to understand how the provision found its way into the final legislation. It made up only eighteen lines out of Dodd-Frank's 2,300 pages, and there were bigger fish to fry. Like other parts of Dodd-Frank, implementation was left to the SEC, where employers kept the issue bottled up for several years. Intense pressure on the SEC to act came from state treasurers and liberal lawmakers such as Senator Elizabeth Warren (D-MA). Now the AFL-CIO began its own letterwriting campaign. In a 3-2 vote along party lines, the SEC in 2015 approved collection of pay-ratio data. The first report using the figures, released by Representative Keith Ellison (D-MN) in 2018, emphasized that executive pay contributed to inequality's upward spiral, the same point that the AFL-CIO had been making for the previous fifteen years. ${ }^{65}$

63 "Wealth of Titans: Fat Stock Options, Payouts Fortify Execs' Compensation," USA Today, April 7, 1999; United for a Fair Economy, Executive Excess 1998: CEOs Gain from Massive Downsizing, Fifth Annual Executive Compensation Survey, Boston, April 23, 1998; “Shareholders Revolt: Is Your CEO Worth \$39 Million?” Workforce Management, January 1, 1999. 64 CEO Compensation in the Post-Enron Era, U.S. Senate, Committee on Commerce, Science, and Transportation, 108th Cong., 1st Sess. (May 20, 2003), 17; "Wal-Mart Stores, Inc., Shareholders' Meeting," Voxant FD, June 2, 2006; "Pay Disparity Disclosure is Focus of Unprecedented New Shareholder Push,” PR Newswire, December 1, 2009; David Webber, The Rise of the WorkingClass Shareholder (Cambridge, MA: Harvard University Press, 2018), 146-48. Donald C. Langevoort,. "The SEC, Retail Investors, and the Institutionalization of the Securities Markets," Virginia. Law Review 95 (2009): 1025-1083.

65 "U.S. Senator Offers Say on Pay, Bonus Clawback Bill," Reuters, February 26, 2010; "Pay Rule Still Unwritten amid Corporate Push," Washington Post, July 7, 2013; "Firms Resist New Pay Equity Rules," Wall Street Journal, June 28, 2012; "Some See Benefits in Publicized Comparisons," International New York Times, August 7, 2015; "Rewarding or Hoarding? An 


\section{Conclusions}

Union investors were the leading shareholder activists of the tumultuous 2000s, a decade of financialization and corporate scandals that ended with a colossal banking crisis. Not often mentioned in discussions of corporate governance is the labor movement, which played a key role in highlighting governance defects related to executive pay, and responding to them via shareholder activism and political engagement. Union investors allied with other shareholders, who supported labor's proposals because they were well-designed and submitted at companies that had governance defects and subpar performance. This was the case even when labor had a collateral interest in persuading a company's employees to join a union.

As compared to other institutional investors, unions had political influence as a result of historically close ties to the Democratic Party, this despite the fact that union density was steadily falling. Liberal politicians and labor unions both cast inequality as a problem related to executive pay. For political figures as for unions, challenging executive pay-setting was one response to voter's concerns about inequality, and for unions it also was a "wedge issue" to support claims that executives were becoming wealthy-sometimes unlawfully-at workers' expense.

There was a conundrum for unions when they advanced their economic and social objectives through shareholder activism: what to do when shareholder and worker interests came into conflict? For all the hubbub about executive compensation, it was small change compared to shareholder payouts. Consider 2007, when share repurchases hit a precrisis peak. That year, the total bill for CEO compensation at the five hundred largest U.S. companies came to $\$ 8.6$ billion, which was 1.4 percent of the total value of stock buybacks. Nine years later, total compensation for the top-five executives at the S\&P 500 was \$18.7 billion, while shareholders at those companies took in around $\$ 1$ trillion in dividends and share repurchases. Shareholder activists always asked if executives received too much. They never asked the same of shareholders. For unions, share repurchases were a tricky issue because they enhanced labor's pension assets. Not until the eve of the presidential election of 2020, when various leftleaning politicians began calling for limits on repurchases, did unions begin to criticize their shortcomings. ${ }^{66}$

Examination of Pay Ratios Revealed by Dodd-Frank," a report prepared by the staff of Representative Keith Ellison, May 20, 2018.

66 Total executive pay was calculated first by multiplying average CEO pay times five hundred. To estimate pay going to the top five, we used the slice data from Bebchuk, Cremers, and Peyer. Admittedly, these are rough calculations, but the order of magnitude is realistic. Lucian A. 
Labor made major contributions to private and public efforts to repair defects with executive pay-setting. It's an irony, however, that a mechanism for advancing shareholder primacy was strengthened by the labor movement. On the other hand, say on pay reinforced claims that corporations were a shareholder democracy in which owners had the right to vote on corporate governance. Say on pay was a precedent for other members of the corporate team-such as employees-to demand a say in corporate governance, as with collective bargaining or proxy access. ${ }^{67}$

Corporate governance has long been the research domain of economists and legal scholars. But in recent years economic historians and political scientists also have explored the subject, using different methods and raising different concerns. For economists, corporations float in markets, what D.H. Robertson famously described as "islands of conscious power in this ocean of unconscious cooperation." 68 But there are other traditions that emphasize the corporation's status as a public entity, imbued with responsibilities and rooted in social norms. The same is true of labor unions. Through private ordering and public regulation, the American labor movement made modest but important contributions to corporate governance during the early twentieth-first century.

\section{Bibliography}

Abrams, R. "Some see benefits in publicized comparisons," International New York Times, August 7, 2015.

Abreu, E. "AFL-CIO asks others to follow a microsoft on options," Reuters, July 9, 2003.

Adamske, S. "Frank introduces legislation to protect shareholders from abuse of executive compensation," US Federal News Service, November 10, 2005.

AFL-CIO. "Statement by AFL-CIO President John J. Sweeney on the need for new rules to ensure corporate accountability,” PR Newswire, July 9, 2002.

AFL-CIO. AFL-CIO NOW, June 30, 2006.

AFL-CIO, "AFL-CIO's paywatch website exposes rigged CEO pay system," PR Newswire, April 5, 2007.

AFL-CIO Executive Council. "Model guidelines for delegated proxy voting responsibility," February 1991.

AFL-CIO, Industrial Union Department. The Stock Option Scandal (Washington, DC: 1959).

Bebchuk, K. J. Martijn Cremers, and Urs C. Peyer, "The CEO Pay Slice," Journal of Financial Economics 102, no. 1 (2011): 199-221; “Two Decades of CEO Pay,” Forbes pay-chart.html 67 Margaret M. Blair and Lynn A. Stout, "A Team Production Theory of Corporate Law," Virginia Law Review 85 (1999): 247-328.

68 D.H. Robertson, The Control of Industry (New York: Harcourt, Brace, 1923): 84. 
Alissa, W. (2015). Boards' response to shareholders' dissatisfaction: The case of shareholders' say on pay in the UK. European Accounting Review, 24, 727-752.

Anand, V. "Council toughens stance," P\&I, February 21, 1994.

Anderson, W. "Senator Schumer and the SEC separately propose action on corporate governance matters," Mondaq, May 22, 2009.

Armstrong, C. S., Gow, I. D., \& Larcker, D. F. (2013). The efficacy of shareholder voting: Evidence from equity compensation plans. Journal of Accounting Research, 51(5), 909-950.

Balsamet, S., Boone, J., Liu, H., \& Yin, J. (2016). The impact of say-on-pay on executive compensation. Journal of Accounting and Public Policy, 35(2), 162-169.

Bauer, R., Moers, F., \& Viehs, M. "The determinants of withdrawn shareholder proposals," SSRN working paper, 2012.

Bebchuk, L. "Insider luck and governance reform," Presentation for Capital Matters, May 2007.

Bebchuk, L., \& Fried, J. (2004). Pay without performance: The unfulfilled promise of executive compensation. Cambridge, MA: Harvard University Press.

Bebchuk, L., Fried, J., \& Walker, D. (2002). Managerial power and rent extraction in the design of executive compensation. University of Chicago Law Review, 69, 751-755.

Bebchuk, L., \& Grinstein, Y. (2005). The growth of executive pay. Oxford Review of Economic Policy, 21, 283-303.

Bebchuk, L. A., Cremers, K. J. M., \& Peyer, U. C. (2011). The CEO pay slice. Journal of Financial Economics, 102(1), 199-221.

Blair, M. M., \& Stout, L. A. (1999). A team production theory of corporate law. Virginia Law Review, 85, 247-328.

Bloomberg, "SEC passes rule changes for options," New York Times, July 1, 2003.

Borosage, R. "Buchanan's challenge: Is anyone listening? The Nation, March 18, 1996.

Brossy, S. 2016 say on pay results, October 12, 2016, http://www.semlerbrossy.com/wp-con tent/uploads/SBCG-2016-Year-End-Say-on-Pay-Report-02-01-2017.pdf.

Brown, L. D., \& Lee, Y. "The impact of SFAS $123 R$ on changes in option-based compensation," SSRN working paper 930818 (2007).

Brunarski, K., Campbell, T. C., \& Harman, Y. (2015). Evidence on outcome of say-on-pay votes: How managers, directors and shareholders respond. Journal of Corporate Finances, 30 , 132-134.

Burns, J. "Labor unions urge members to oppose cox as SEC chairman," Dow Jones Newswire, July 12, 2005.

Burns, J. "U.S. House lawmakers clash on issue of CEO pay," Dow Jones Newswires, May 26, 2006.

Burr, B. "Joint effort: Union funds using proxy resolution as lobbying tool," Pensions \& Investments, June 9, 2003.

Burr, B. "Disclosure rule to ease executive pay comparisons," Pensions \& Investments, September 4, 2006.

Burr, B. "Union funds champs of proxy season," Pensions \& Investments, February 5, 2007.

Burr, B., "Shareholders see victory in Obama administration," Pensions \& Investments, November 10, 2008.

Cai, J., Garner, J. L., \& Walkling, R. A. (2009). Electing directors. Journal of Finance, 64(5), 23892421.

Cai, J., \& Walkling, R. A. (2011). Shareholders' say on pay: Does it create value? Journal of Financial and Quantitative Analysis, 46(2), 299-339. 
Carola, F., \& Saks, R. E. (2010). Executive compensation: A new view from a long-term perspective, 1936-2005. Review of Financial Studies, 23, 2099-2138.

Carolan, M. "Vodafone board faces TUC opposition over pay awards," Dow Jones Newswires, July 20, 2002.

Cho, D. "U.S. Targets excessive pay for top executives," Washington Post, June 11, 2009.

Choi, S., \& Fisch, J. (2008). On beyond CalPERS: Survey evidence on the developing role of public pension funds in corporate governance. Vanderbilt Law Review, 61, 315-354.

Choi, S., Fisch, J., \& Kahan, M. (2010). The power of proxy advisors: Myth or reality? Emory Law Journal, 59, 869.

Choi, S. J., Wiechman, A., \& Pritchard, A. C. (2013). Scandal enforcement at the SEC: The arc of the option backdating investigations. American Law and Economics Review, 15, 542-577.

Clark, C. (1999). Executive pay: Do CEOs get paid too much. CQ Researcher, 7(July), 11.

Communications, C. "Most CFAs back the vote on executive pay," Investment News, April 2, 2007.

Conference Board. (2003). Commission on public trust and private enterprise. New York: Author.

Conor, P. TIAA-CREF endorses governance reforms proposed by NYSE panel," CSR News, June 6, 2002.

Conyon, M. J. (2013). Executive compensation and board governance in US firms. Economic Journal, 124, F60-F89.

Conyon, M. J., \& Murphy, K. J. (2000). The prince and the pauper? CEO pay in the United States and United Kingdom. The Economic Journal, 110(467), 640-661.

Cooper, M. J., Gulen, H., \& Rau, R. "Performance for pay? The relation between CEO incentive compensation and future stock price performance," SSRN working paper 1572085 , November 1, 2016.

Correa, R., \& Lel, U. "Say on pay laws, executive compensation, CEO pay slice, and firm value around the world," FBR International Finance Discussion Paper no. 1084 (2013).

Cotter, J. F., Palmiter, A. R., \& Thomas, R. S. (2013). The first year of say-on-pay under Dodd-Frank: An empirical analysis and look forward. The George Washington Law Review, 91, 967-1011.

Cremers, K. J. M., \& Grinstein, Y. (2013). Does the market for CEO talent explain controversial CEO pay practices? Review of Finance, 18, 921-960.

Creswell, J. "With links to board, chief saw his pay soar," New York Times, May 24, 2006.

Cuñat, V., Gine, M., \& Guadalupe, M. (2016). Say pays! shareholder voice and firm performance. Review of Finance, 20, 1799-1834.

Dash, E. "Congress is urged to hold off acting on options and pay," New York Times, September 7, 2006.

Davenport, T., “Countrywide shareholders to vote on exec-pay proposal,” American Banker, June $14,2006$.

Deakin, S. (2005). The coming transformation of shareholder value. Corporate Governance, 13 , 11-18.

DeCarlo, S. "Two decades of CEO pay," Forbes, https://www.forbes.com/lists/2012/12/ceocompensation-12-historical-pay-chart.html.

Demery, P. "FASB caves in on stock options," Practical Accountant, February 1, 1995

Deutsch, C. (2006, April 9). Behind big dollars, worrisome boards. New York Times.

Deutsch, C. "A brighter spotlight, yet the pay rises," New York Times, April 6, 2008.

Dew-Becker, I., \& Gordon, R. J. "Where did the productivity growth go? Inflation dynamics and the distribution of income," National Bureau of Economic Research working paper no. w11842, 2005. 
DiNardo, J., Hallock, K., \& Pischke, J.-S. “Unions and managerial pay,” working paper no. 6318, National Bureau of Economic Research, 1997.

Drapkin, D. "Stock option timing: The scrutiny intensifies, Mondaq Business Briefing, July 31, 2006.

Drawbaugh, K. “U.S. Rep. Frank: Say-on-pay would test directors,” Reuters, March 19, 2007.

Drawbaugh, K. "U.S. Senator offers say on pay, bonus clawback bill," Reuters, February 26, 2010.

Drucker, P. F. (1984, April 24). Reform executive pay or congress will. Wall Street Journal.

Drucker, P. F. (2011). Frontiers of management (pp. 138-143). New York: Routledge.

Eaglesham, J. “Executive pay law 'Nightmare' on wall street," Financial Times, August 30, 2010.

Edmans, A., \& Gabaix, X. (2009). Is CEO pay really inefficient? A survey of new optimal contracting theories. European Financial Management, 15(3), 486-496.

Eisinger, J. "In shareholder say-on-pay votes, more whispers than shouts," New York Times, June 26, 2013.

Elstein, A. "Push for say on pay is losing its Oomph," Crain's New York Business, June 23, 2008.

Elstein, A. "A corporate watchdog's bark has companies growling back," Crain's New York Business, June 27, 2011.

Equilar. (2016). 2016 CEO compensation pay trends. Redwood City, CA.

Ertimur, Y., Ferri, F., \& Maber, D. A. (2012). Reputation penalties for poor monitoring of executive pay: Evidence from option backdating. Journal of Financial Economics, 104, 118-144.

Ertimur, Y., Ferri, F., \& Muslu, V. (2011). Shareholder activism and CEO pay. Review of Financial Studies, 24, 535-592.

Ertimur, Y., Ferri, F., \& Oesch, D. (2013). Shareholder votes and proxy advisors: Evidence from say on pay. Journal of Accounting Research, 51, 951-996.

Fama, E. F., \& Jensen, M. C. (1983). Agency problems and residual claims. The Journal of Law and Economics, 26(2), 327-349.

Feller, B. "Bush takes aim at companies' Lavish executive pay," Associated Press, January 31, 2007.

Ferguson, C. (2014). Inside job: The financiers who pulled off the heist of the century. London: Oneworld.

Ferri, F., Markarian, G., \& Sandino, T. "Stock options expensing: Evidence from shareholders' votes," European Accounting Association Annual Congress, Goteborg, 2005.

Ferri, F., \& Sandino, T. (2009). The impact of shareholder activism on financial reporting and compensation: The case of employee stock option expensing. The Accounting Review, 84, 433-466.

Ferri, F., \& Weber, J. "AFSCME vs. Mozilo ... and "Say on Pay" for all! (A)," Harvard Business School, case study 9-109-009, March 18, 2009.

Fligstein, N., \& Roehrkasse, A. F. (2016). The causes of fraud in the financial crisis of 2007 to 2009: Evidence from the Mortgage-backed securities industry. American Sociological Review, 81(4), 617-643.

Forelle, C. (2006, March 18). The perfect payday. Wall Street Journal.

Frydman, C., \& Jenter, D. (2010). CEO compensation. Annual. Review Financial. Economics, 2, 75-102.

Gabaix, X., \& Landier, A. (2008). Why has CEO pay increased so much? The Quarterly Journal of Economics, 123(1), 49-100. 
Gabaix, X., Landier, A., \& Sauvagnat, J. (2014). CEO pay and firm size: An update after the crisis. Economic Journal, 124, F-60-F89.

Galloni, A. (2002, July 11). Executive pay is at issue. Wall Street Journal: Europe.

Gavett, G. "CEOs get paid too much, according to nearly everyone in the world," Harvard Business Review, September 23, 2013.

Georgeson, Annual Corporate Governance Review (ACGR), various years.

Giannone, J., "Investors push 90 companies for say on CEO pay," Reuters, January 24, 2008.

Goldstein, M. "The state of engagement between U.S. corporations and shareholders," IRRC Institute, February 22, 2011.

Gomez, R., \& Tzioumis, K. “What do unions do to CEO compensation?” Discussion paper 720, Centre for Economic Performance, London School of Economics, May 2006.

Gordon, M., "Excessive executive pay eroding investor confidence," Associated Press, May 20, 2003.

Gordon, M. "Say on pay bills more cudgel than reality," Associated Press, June 15, 2008.

Graham, J. R., Lang, M. H., \& Shackelford, D. A. (2004). Employee stock options, corporate taxes, and debt policy. Journal of Finance, 59, 1589.

Greenhouse, S. "Labor puts executive pay in the spotlight," New York Times, April 9, 2011.

Greider, W., "Not wanted: Enron democrats," The Nation, April 8, 2002.

Grinstein, Y., Weinbaum, D., \& Yehuda, N. "Perks and excess: Evidence from the new executive compensation disclosure rules," Working paper no. 04-09, Cornell University, Johnson School Research Paper Series, 2008.

Grow, D., "Sabo fights lonely fight of old-fashioned liberal," Minneapolis Star-Tribune, February 10, 1997.

Guth, R. (2003, July 9). Tarnished gold: Microsoft ushers out era of options. Wall Street Journal.

Hacker, J. S., \& Pierson, P. (2010). Winner-take-all politics: Public policy, political organization, and the precipitous rise of top incomes in the United States. Politics and Society, 38, 152-204.

Hambrick, D. C., \& Mason, P. A. (1984). Upper echelons: The organization as a reflection of its top managers. Academy of Management Review, 9(2), 193-206.

Harris, J., \& Bromiley, P. (2007). Incentives to cheat: The influence of executive compensation and firm performance on financial misrepresentation. Organization Science, 18(3), 350367.

Harry, W. "Groups blast home depot over stock option mistake," Associated Press, June 29, 2006.

Henry, D. "Options scandal in U.S. set to grow further," Bloomberg News, August 4, 2006.

Herbst, M. "Investor outcry over exec pay retreat," Business Week, December 28, 2006.

Heron, R. A., \& Lie, E. (2009). What fraction of stock option grants to top executives have been backdated or manipulated? Management Science, 54, 513-525.

Hilzenrath, D. "How congress rode a storm to corporate reform," Washington Post, July 28, 2002.

Hilzenrath, D. "New SEC rules make pay more transparent," Washington Post, July 16, 2007.

Huang, Q., Jiang, F., Lie, E., \& Que, T. (2017). The effect of labor unions on CEO compensation. Journal of Financial and Quantitative Analysis, 52(2), 553-582.

Hughes, S. “Investors oppose SEC's Exec-pay disclosure change," Dow Jones Newswire, January 31, 2007.

Hughes, S., \& Godfrey, J. (2005, November 10). House democrat targets executive pay. Wall Street Journal. 
ICCR, "Shareholders challenge goldman sachs as it prepares to pay record bonuses," $P R$ Newswire, October 14, 2009.

ICCR, "Pay disparity disclosure is focus of unprecedented new shareholder push," PR Newswire, December 1, 2009.

Iliev, P., \& Vitanova, S. "The effect of say on pay vote in the U.S.," Working paper, Pennsylvania State University, February 2015.

Institute for Policy Studies. Executive Excess: Annual CEO Compensation Survey, 2003-2007.

ISS. "Director elections and majority voting," ISS Governance Weekly, July 13, 2007.

Iwata, E. "Backdated options may snare some directors as critics blast rubber-stamping," USA Today, March 29, 2007.

Jacoby, S. M. "For more honesty with stock options," Christian Science Monitor, July 29, 2002.

Jensen, M. C. " How stock options reward managers for destroying value and what to do about it," Harvard Business School, Working paper No. 04-27, April 2001.

Jensen, M. C., \& Murphy, K. J. (1990). Performance pay and top-management incentives. Journal of Political Economy, 98, 225-264.

Johnson, C. (2003, November 5). HealthSouth founder is charged with fraud.Washington Post.

Johnson, S. "House committee probes executive-pay consultants," CFO.com, December 5, 2007. June 27, 2011.

Kaplan, S. N. (2008). Are U.S. CEOs overpaid? Academy of Management Perspectives, 23, 5-20.

Kaplan, S. N., \& Rauh, J. "Wall street and main street: What contributes to the rise in the highest incomes?” NBER working paper 13270 (2007).

Kary, T. "Shareholders to target options backdaters in 2007 proxies" Dow Jones Newswire, October 26, 2006.

Keith, E., "Rewarding or hoarding? An examination of pay ratios revealed by Dodd-Frank," A report prepared by the staff of Representative Keith Ellison, May 20, 2018.

Khurana, R. (2002). Searching for a corporate savior: The irrational quest for charismatic CEOs. Princeton, NJ: Princeton University Press.

Kollmeyer, C., \& Peters, J. (2019). Financialization and the decline of organized labor: A study of 189 advanced capitalist countries, 1970-2012. Social Forces, 98, 1-30.

Krugman, P. (1994). Peddling prosperity: Economic sense and nonsense in the age of diminished expectations. New York: W.W. Norton.

Kruse, D. L., Blasi, J. R., \& Park, R. (2010). Prevalence, characteristics, and employee views of financial participation in enterprises. In B. Kruse, \& R. B. Freeman (Eds.), Shared capitalism at work. Chicago: University of Chicago Press.

Kwoh, L. (2012, June 28). Firms resist new pay equity rules. Wall Street Journal.

Labaton, S. "In victory for Obama, house panel approves restraints on executive pay," New York Times, July 29, 2009.

Larcker, D. F., \& Tayan, B. "Union activism: Do union pension funds act solely in the interest of beneficiaries?" Rock Center for Corporate Governance Stanford University, working paper CGRP-30 (2012).

Lavelle, L. "This options-expensing bill is no reform," Business Week, November 25, 2003.

Lehner, T. J. Statement to house financial services committee, "Written Testimony and Comments for the Record," May 25, 2006.

Lewis, D. "Unions take fight over CEO's pay to shareholders," Knight-Ridder Business News, April 11, 1999.

Lie, E. (2005). On the timing of CEO stock option awards. Management Science, 51, 802-881.

Liedtke, M. "Tech industry challenges reform," Los Angeles Times, May 20, 2003. 
Lloyd, M. E. "AFL-CIO: Meeting with home depot Dir. Hill productive," Dow Jones News Service, September 7, 2006.

Lloyd, M. E. "Home depot defends CEO pay but reviewing policies," Dow Jones News Service, September 18, 2006.

Lohr, S. "Wall St pay moves in cycles. (Guess where we are now)," New York Times, February 5, 2009.

Lowenstein, R. (2004). Origins of the crash: The great bubble and its undoing. New York: Penguin.

Lublin, J. S. (2003, April 14). Why the get-rich-quick days may be over. Wall Street Journal.

Lublin, J. S. (2007, April 9). CEO compensation survey. Wall Street Journal.

Lublin, J. S. (2007, January 4). Behind Nardelli's Abrupt exit. Wall Street Journal.

Lublin, J. S. (2008, July 21). New breed of directors reaches out to shareholders. Wall Street Journal.

Lucchetti, A. (2011, February 7). Companies fight back on executive pay. Wall Street Journal.

Maremont, M. (2005, November 11). Authorities probe improper backdating of options. Wall Street Journal.

Marens, R. (2008). Going to war with the army you have: Labor's shareholder activism in an era of financial hegemony. Business and Society, 47, 312-342.

Markon, J. "Pay rule still unwritten amid corporate push," Washington Post, July 7, 2013.

McLaughlin, T., "Executive pay under spotlight at annual meeting," Reuters, April 22, 2003.

Mishel, L. "Unions, inequality, and faltering middle-class wages," Economic Policy Institute, Issue Brief no. 342, August 29, 2012.

Mishel, L., \& Davis, A. "Top CEOs make 300 times more than typical workers: Pay growth surpasses stock gains and wage growth of top 0.1 percent," Economic Policy Institute, June 21, 2015.

Mishel, L., \& Sabadish, N. "CEO pay in 2012 was extraordinarily high relative to typical workers and other high earners," Economic Policy Institute, June 26, 2013.

Mishel, L., \& Schieder, J. "Stock market headwinds meant less generous year for some CEOs," Economic Policy Institute, July 12, 2016.

Mogul, M. "New SEC rules to lift the veil on CEO pay," Kiplinger Business Forecasts, December 9, 2005.

Morgenson, G. "Business lobby seeks to limit investor votes on options," New York Times, June 6, 2002.

Morgenson, G. (2002, July 11). Bush failed to stress need to rein in stock options. Wall Street Journal.

Morgenson, G. “Roadblocks to greater say on pay,” New York Times, January 21, 2007.

Morgenson, G. "How big a payday for the pay consultants?” New York Times, June 22, 2008.

Morgenson, G. "When shareholders make their voices heard," New York Times, April 7, 2012.

Morgenson, G., "Shareholders' votes have done little to curb lavish executive pay," New York Times, May 16, 2015.

Murphy, K. J. "The politics of pay: A legislative history of executive compensation," Marshall School of Business working paper no. FBE-1 (2011).

Nagy, D. M. (2004). Playing Peekaboo with constitutional law: The PCAOB and its public/private status. Notre Dame Law Review, 80, 988.

Nelson-Horchler, J. "What's your boss worth? 35 times your salary? 1,000 times? The workforce gets angry," Washington Post, August 5, 1990.

Nocera, J., “Donaldson: The exit interview," New York Times, July 23, 2005. 
Norris, F. "Accounting board yields on stock options," New York Times, December 15, 1994. Norris, F., "Software company shareholders demand a voice in issuing of stock options," New York Times, May 9, 2002.

Norris, F. "Coke to report options as an expense," New York Times, July 15, 2002.

O'Brien, S. "Find one on one," Investment News, August 5, 2002.

Orr, A. "Calif., Other states urge more corporate reforms," Reuters, June 30, 2003.

Paletta, D. "US rep frank calls on businesses for wages, trade deal," Dow Jones Newswires, January 3, 2007.

Payne, H. "AFL-CIO head calls for grass-roots campaign against corporate greed," AP Newswire, July 30, 2002.

Peng, L., \& Roell, A. (2008). Executive pay and shareholder litigation. Review of Finance, 12(1), 141-184.

Peterson, J. "House votes to have shareholders weigh in on exec pay," Los Angeles Times, April 21, 2007.

Phillopon, T., \& Reshef, A. (2012). Wages and human capital in the US finance industry: 19092006. Quarterly Journal of Economics, 127, 1551-1609.

Plitch, P. "Teamsters enter options war with battle against tech co," Dow Jones News Service, October 17, 2002.

Plitch, P. (2006, May 24). Home depot annual meeting ground zero in pay debate. Wall Street Journal.

Prevost, A. K., Rao, R. P., \& Williams, M. A. (2012). Labor unions as shareholder activists: Champions or detractors? Financial Review, 47, 327-349.

Prevost, A. K., \& Wagster, J. D. "Impact of the 1992 changes in the SEC proxy rules and executive compensation requirements," Unpublished paper, September 1999.

Rachel, S. Heads I Win, Tails I Win: More companies offer bonus payments that aren't tied to performance," Wall Street Journal, April 6, 2000.

Rapoport, M., "Letter campaigns try to sway FASB on option expensing," Dow Jones Newswires, May 18, 2004.

Rapoport, M. “Group of big pension funds, unions, urges option expensing," Dow Jones Newswire, May 19, 2004.

Rees, B. J. T., Protecting investors and fostering efficient capital markets: Hearings before the committee on financial services, U.S. House of Representatives, 109th Cong., 2nd Sess. (May 25, 2006).

Reidy, C. "Frank's bill seeks greater disclosure of executive pay," Boston Globe, November 11, 2005.

Renneboog, L., \& Szilagyi, P. (2010). "The success and relevance of shareholder activism through proxy proposals,” European Corporate Governance Institute - Finance Working Paper, 275/2010, March 2010

Renneboog, L., \& Szilagyi, P. (2011). The role of shareholder proposals in corporate governance. Journal of Corporate Finance, 17, 167-188.

Riley, C. (2006, August 25). Citigroup payouts of chiefs Irk holders. Wall Street Journal.

RiskMetrics Group. 2007 Postseason Report, New York, 2008.

Rivlin, G. "Silicon valley was calming down. Now an options scandal," New York Times, July 22, 2006.

Roberts, D. "Business leaders welcome tighter rules but now some claim the reforms are doing more harm than good," Financial Times, June 1, 2004.

Robertson, D. H. (1923). The control of industry. New York: Harcourt, Brace. 
Rose, P. (2007). The corporate governance industry. Journal of Corporation Law, 32, 887-926.

Rose, R. "Call to action: Labor has discovered the perfect issue for galvanizing workers," New York Times, April 9, 1996.

Sabo, M., "No one should be left behind in our nation's new economy," Tax Foundation's Tax Features, October 1, 1999.

Sanders, W., \& Hambrick, D. C. (2007). Swinging for the fences: The effects of CEO stock options on company risk taking and performance. Academy of Management Journal, 50, 1055-1078.

Scannell, K. (2009, March 26). Policy makers work to give shareholders more boardroom clout. Wall Street Journal.

Scannell, K., \& Lublin, J. S. (2006, July 27). SEC issues rules on executive pay, options grants. Wall Street Journal.

Scheiber, N., "For the wealthiest, a private tax system that saves them billions," New York Times, December 29, 2015.

Schneider, C. "Congress, FASB in stock option flap," CFO.com, June 6, 2003.

Schneider, C. "Cisco and FASB: Options showdown," CFO.com, May 24, 2004.

$\mathrm{SEC}$. "SEC votes to adopt changes to disclosure requirements concerning executive compensation and related matters," SEC Press Release 2006-123, July 26, 2006.

Shin, T. (2016). Fair pay or power play? Pay equity, managerial power, and compensation adjustments for CEOs. Journal of Management, 42, 419-448.

Silvers, D. A., \& Garland, M. I. "The origins and goals of the fight for proxy access" (2004), https://www.sec.gov/spotlight/dir-nominations/silversgarland022004.pdf.

Simon, E., "Everyone from pres. Bush to union activists asks: How can CEO pay be brought down to earth?" Associated Press Newswires, February 9, 2007.

Solomon, D. (2005, June 2). SEC chairman makes early exit. Wall Street Journal.

Solomon, D., \& McKinnon, J. (2005, June 2). Donaldson ends an SEC tenure marked by active regulation. Wall Street Journal.

Stempel, J. AFSCME urges US companies to curb executive pay," Reuters, December 7, 2005.

Stone, P. H. (2003, March 1). Corporate reform, back on the front burner. National Journal.

Stout, L. (2012). The shareholder value myth: How putting shareholders first harms investors, corporations, and the public. San Francisco: Berrett-Koehler Publishers.

Stout, L. A. (2012, June). New thinking on shareholder primacy. accounting, economics, and Law: A Convivium, 2. at DOI. doi:https://doi.org/10.1515/2152-2820.1037

Strauss, G. "Wealth of titans: Fat stock options, payouts fortify execs' compensation," USA Today, April 7, 1999.

Stuart, H. "The day investors said enough is enough," The Guardian, May 20, 2003.

Styre, S. "Shareholders have the floor," Boston Globe, January 2, 2003.

Sunoo, B. "Shareholders revolt: Is your CEO worth \$39 million?" Workforce Management, January 1, 1999.

Taub, S. "Obama pushes say on pay," CFO.com, April 11, 2008.

Taub, S., “Labor of love," Institutional Investor, March 14, 2005.

Taylor, L. A. (2013). CEO wage dynamics: Estimates from a learning model. Journal of Financial Economics, 108(1), 79-98.

Thomas, R. S., Parmiter, A. R., \& Cotter, J. F. (2012). Dodd-Frank's say on pay: Will it lead to a greater role for shareholders in corporate governance? Cornell Law Review, 97, 1213-1266.

Thomas, R. S., \& Van der Elst, C. (2015). Say on pay around the world. Washington University Law Review, 92, 653-731. 
Toner, R. "A new populism spurs democrats on the economy," New York Times, July 16, 2007. Trejos, N., "How much does your CEO really make? Go figure," Washington Post, February 8, 2009.

Tse, T. "Say on pay movement loses steam," Washington Post, May 6, 2008.

Tuna, C. (2009, January 12). Shareholders to focus on executive compensation. Wall Street Journal.

Tuna, C. (2009, September 2). Investors say yes on pay at TARP firms. Wall Street Journal.

U.S. General Accounting Office (GAO), Corporate shareholder meetings: Issues relating to firms that advise institutional investors on proxy Voting (Washington, DC, June 2007).

U.S. House Subcommittee on Commerce, Trade, and Consumer Protection. SB Proposals on Stock Option Expensing: Serial 108-99, July 8, 2014.

U.S. Senate, Committee on commerce, science, and transportation, 108th Cong., 1st Sess., CEO Compensation in the Post-Enron Era, May 20, 2003 (Washington: U.S. GPO, 2006), 15-17.

United for a Fair Economy. Executive excess 1998: CEOs gain from massive downsizing, Fifth Annual Executive Compensation Survey, Boston, April 23, 1998.

US Fed News. "Rep. Sabo introduces income equity act of 2005," US Federal News, July 12, 2005.

Walter, P. Former healthsouth CEO, Richard Scrushy, gets prison sentence reduced," Forbes, January 26, 2012.

Webber, D. (2018). The rise of the working-class shareholder. Cambridge, MA: Harvard University Press.

Webel, B., \& Lebonte, M. Troubled Asset Relief Program (TARP): Implementation and status, Report by the Congressional Research Service, June 27, 2013.

Weber, H. "Home depot CEO nailed over pay," Associated Press, May 26, 2006.

Wells, H. (2012). U.S. Executive compensation in historical perspective. In R. S. Thomas, \& J. G. Hill (Eds.), Research handbook on executive compensation (pp. 41-57). Cheltenham, UK: Elgar.

Western, B., \& Rosenfeld, J. (2011). Unions, norms, and the rise in US wage inequality. American Sociological Review, 76, 513-537.

Weston, L. P. “Despite recession, perks for top executives grow," Los Angeles Times, February 1, 2002.

White, E. (2007, February 26). Shareholders push for vote on executive pay. Wall Street Journal.

Whitehouse, K., \& Plitch, P. "Even with disclosure, investors have little say on pay," Dow Jones Newswires, January 31, 2006.

Whitehouse, K., \& Plitch, P. (2006, February 7). Executive pay debate highlights minimal power of shareholders. Wall Street Journal.

Whitehouse, K., \& Plitch, P. "Funds urge SEC to rethink pay-for-performance disclosures," Dow Jones Newswires, April 12, 2006.

Wood, R. W. "Tax savvy execs work for \$1, get paid millions as capital gains," Forbes, May 2, 2016.

Wowak, A. J., Mannor, M. J., \& Wowak, K. D. (2014). Throwing caution to the wind: The effect of CEO stock option pay on the incidence of product safety problems. Strategic Management Journal, 36, 1082-1092.

Article note: This paper is dedicated to the memory of Lynn Stout. Her wit, warmth, and penetrating mind will be missed. 